\title{
Process analysis and sensitivity study of regional ozone formation over the Pearl River Delta, China, during the PRIDE-PRD2004 campaign using the Community Multiscale Air Quality modeling system
}

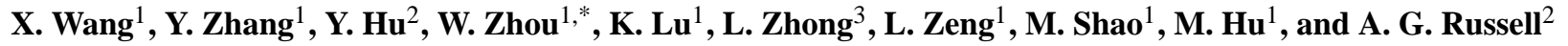 \\ ${ }^{1}$ State Key Joint Laboratory of Environmental Simulation and Pollution Control, College of Environmental Sciences and \\ Engineering, Peking University, Beijing, China \\ ${ }^{2}$ School of Civil and Environmental Engineering, Georgia Institute of Technology, Atlanta, Georgia, USA \\ ${ }^{3}$ Guangdong Provincial Environmental Monitoring Center, Guangzhou, China \\ *now at: Department of Civil and Environmental Engineering, Rice University, Houston, Texas, USA
}

Received: 22 October 2009 - Published in Atmos. Chem. Phys. Discuss.: 15 December 2009

Revised: 29 April 2010 - Accepted: 29 April 2010 - Published: 12 May 2010

\begin{abstract}
In this study, the Community Multiscale Air Quality (CMAQ) modeling system is used to simulate the ozone $\left(\mathrm{O}_{3}\right)$ episodes during the Program of Regional Integrated Experiments of Air Quality over the Pearl River Delta, China, in October 2004 (PRIDE-PRD2004). The simulation suggests that $\mathrm{O}_{3}$ pollution is a regional phenomenon in the Pearl River Delta (PRD). Elevated $\mathrm{O}_{3}$ levels often occurred in the southwestern inland PRD, Pearl River estuary (PRE), and southern coastal areas during the 1-month field campaign. Three evolution patterns of simulated surface $\mathrm{O}_{3}$ are summarized based on different near-ground flow conditions. More than $75 \%$ of days featured interactions between weak synoptic forcing and local sea-land circulation. Integrated process rate (IPR) analysis shows that photochemical production is a dominant contributor to $\mathrm{O}_{3}$ enhancement from 09:00 to 15:00 local standard time in the atmospheric boundary layer over most areas with elevated $\mathrm{O}_{3}$ occurrence in the mid-afternoon. The simulated ozone production efficiency is $2-8 \mathrm{O}_{3}$ molecules per $\mathrm{NO}_{\mathrm{x}}$ molecule oxidized in areas with high $\mathrm{O}_{3}$ chemical production. Precursors of $\mathrm{O}_{3}$ originating from different source regions in the central PRD are mixed during the course of transport to downwind rural areas during nighttime
\end{abstract}

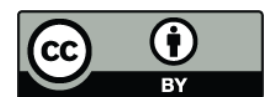

Correspondence to: Y. Zhang (yhzhang@pku.edu.cn) and early morning, where they then contribute to the daytime $\mathrm{O}_{3}$ photochemical production. The sea-land circulation plays an important role on the regional $\mathrm{O}_{3}$ formation and distribution over PRD. Sensitivity studies suggest that $\mathrm{O}_{3}$ formation is volatile-organic-compound-limited in the central inland PRD, PRE, and surrounding coastal areas with less chemical aging $\left(\mathrm{NO}_{\mathrm{x}} / \mathrm{NO}_{\mathrm{y}}>0.6\right)$, but is $\mathrm{NO}_{\mathrm{x}}$-limited in the rural southwestern PRD with aged air $\left(\mathrm{NO}_{\mathrm{x}} / \mathrm{NO}_{\mathrm{y}}<0.3\right)$.

\section{Introduction}

Tropospheric ozone $\left(\mathrm{O}_{3}\right)$ is a secondary pollutant produced through a series of photochemical reactions involving mainly nitrogen oxides $\left(\mathrm{NO}_{\mathrm{x}}\right)$ and volatile organic compounds (VOCs) in the presence of sunlight. Elevated concentration of ground-level $\mathrm{O}_{3}$ is of great environmental concern due to its adverse impacts on human health and ecosystems, as well as its greenhouse effect (NARSTO, 2000). The $\mathrm{O}_{3}$ pollution in megacities and regional areas has been investigated recently by many studies (Evtyugina et al., 2006; Gonçalves et al., 2009; Lei et al., 2007; Kimura et al., 2008; Yu et al., 2009; Chang, 2008; Ran et al., 2009; Wang et al., 2009 ), in which the topics addressed include $\mathrm{O}_{3}$ photochemical production, chemical sensitivity to precursors, roles of

Published by Copernicus Publications on behalf of the European Geosciences Union. 
meteorological conditions, $\mathrm{O}_{3}$ source attributions and development of control strategy.

The Pearl River Delta (PRD) is one of the most urbanized and industrialized regions in southern China. This area contains three megacities (Guangzhou, Shenzhen, and Hong Kong) and numerous medium and small cities, houses $4 \%$ of the total population of China, and produces about 19\% of China's gross domestic product each year. As a consequence of the substantial economic development and increases in air pollutant emissions, in recent years, the PRD has experienced rapid deterioration of air quality. Photochemical smog has been one of the most severe air quality issues in the PRD, where surface $\mathrm{O}_{3}$ levels exceeding the national hourly standard of $200 \mu \mathrm{g} / \mathrm{m}^{3}$ ( $\left.\sim 0.093 \mathrm{ppm}\right)$ are frequently observed by air quality monitoring networks, especially in fall when northerly winds and clear sky conditions prevail (Wang et al., 2001, 2003; Zhang et al., 2007, 2008a).

The $\mathrm{O}_{3}$ pollution in Hong Kong has raised much attention over the past decade. Meteorological conditions have been found to be closely associated with $\mathrm{O}_{3}$ pollution in Hong Kong and the Pearl River estuary (PRE) area. The synoptic systems related to $\mathrm{O}_{3}$ episodes in Hong Kong have been classified into three patterns: tropical cyclones, continental anticyclones, and low-pressure troughs (Huang, et al., 2005, 2006; Chan and Chan, 2000). The impacts of the complex topography, local circulations, and low mixing height on heavy $\mathrm{O}_{3}$ pollution were investigated ( $\mathrm{Liu}$ and Chan, 2002; Ding et al., 2004; Lam et al., 2005), and a conceptual model was developed to explain the effect of land-sea breezes on pollutant transport, trapping, and accumulation (Lo et al., 2006). In addition, the local versus regional contributions to $\mathrm{O}_{3}$ episodes in Hong Kong have been widely investigated using chemical transport models (CTMs) and a backward trajectory method (Ding et al., 2004; Lam et al., 2005; Huang et al., 2005, 2006; Wang et al., 2006; Zhang et al., 2007). The relative importance of local production and of regional transport from inland parts of the PRD was found to change under different meteorological conditions and at different locations. Previous studies have also addressed the relationship between $\mathrm{O}_{3}$ and its precursors. In Hong Kong, the photochemical formation of $\mathrm{O}_{3}$ is generally believed to be VOC-limited (Chan and Yao, 2008).

However, $\mathrm{O}_{3}$ pollution in the $\mathrm{PRD}$ region outside of Hong Kong and PRE has not yet been investigated adequately, and only limited studies have been reported. Wang et al. (2005) evaluated the importance of different emission sources on the concentrations of $\mathrm{O}_{3}$ and other pollutants for the whole PRD in March 2001. Wei et al. (2007) investigated the impact of biogenic $\mathrm{VOC}$ emissions on $\mathrm{O}_{3}$ formation. Zhang et al. (2008b) and Shao et al. (2009) adopted an observationbased model to investigate $\mathrm{O}_{3}$ production sensitivity to precursors in Guangzhou. CTMs are useful tools for exploring the spatiotemporal evolution of $\mathrm{O}_{3}$ pollution and assessing the roles of different atmospheric processes in $\mathrm{O}_{3}$ formation. In spite of the works by Wang et al. (2005) and Wei et al. (2007), there are still very limited three-dimensional (3-D) modeling studies to address these issues over the inland PRD region. Moreover, to develop effective strategies for $\mathrm{O}_{3}$ pollution control, our understanding of $\mathrm{O}_{3}-\mathrm{VOC}-\mathrm{NO}_{\mathrm{x}}$ chemistry over the whole PRD needs to be improved through more observational and modeling studies.

The Program of Regional Integrated Experiments of Air Quality over the Pearl River Delta, China, in October 2004 (PRIDE-PRD2004) obtained a comprehensive database of $\mathrm{O}_{3}$, particulate matter, and other air pollutant measurements in this region (Zhang et al., 2008a), providing an ideal testbed for CTM application to thoroughly investigate the spatiotemporal evolution and chemical characteristics of ground-level $\mathrm{O}_{3}$ pollution over the whole $\mathrm{PRD}$ region.

In this paper, the US Environmental Protection Agency (EPA) Community Multiscale Air Quality (CMAQ) modeling system is applied to simulate $\mathrm{O}_{3}$ episodes during the PRIDE-PRD2004 campaign. Our goal is to quantify the impacts of different chemical and physical processes on elevated $\mathrm{O}_{3}$ formation and to characterize the regional $\mathrm{O}_{3}$ chemical production over the entire PRD area. Section 2 describes the modeling methodology. Section 3 presents and discusses the model performance, the spatiotemporal evolution of elevated $\mathrm{O}_{3}$, the influence of different processes on $\mathrm{O}_{3}$ formation, and the characteristics of $\mathrm{O}_{3}$ chemical production. A summary of conclusions is provided in Sect. 4.

\section{Methodology}

\subsection{Model setup and inputs}

We use CMAQ (version 4.5, Byun and Schere, 2006) with the Statewide Air Pollution Research Center version 99 (SAPRC-99) chemical mechanism (Carter, 2000) to simulate $\mathrm{O}_{3}$ formation during the whole month of October 2004. The model is configured to have triple-nested domains (Fig. 1). The outer domain with a horizontal grid spacing of $36 \mathrm{~km}$ covers the entire area of China, the $12-\mathrm{km}$ grid-spacing inner domain covers Guangdong, Hong Kong, and Macao, and the innermost domain with a 4-km horizontal grid resolution focuses on the PRD. All the grids have 13 layers vertically extending from the surface to an altitude of $\sim 17 \mathrm{~km}$ above the ground, with seven layers below $1 \mathrm{~km}$ and the first layer thickness of $\sim 19 \mathrm{~m}$. The outputs from the outer domains are used to provide boundary conditions for the inner ones by one-way nesting. A spin-up period of 3 days (1-3 October) is used to minimize the influence of initial conditions.

The fifth-generation Pennsylvania State University/National Center for Atmospheric Research (PSU/NCAR) Mesoscale Model (MM5, version 3.7) (Grell et al., 1994) is used to simulate the meteorological fields to drive CMAQ. MM5 is configured with the same nested horizontal domains as those for CMAQ (except that at least three grid cells are extended from each side of the 


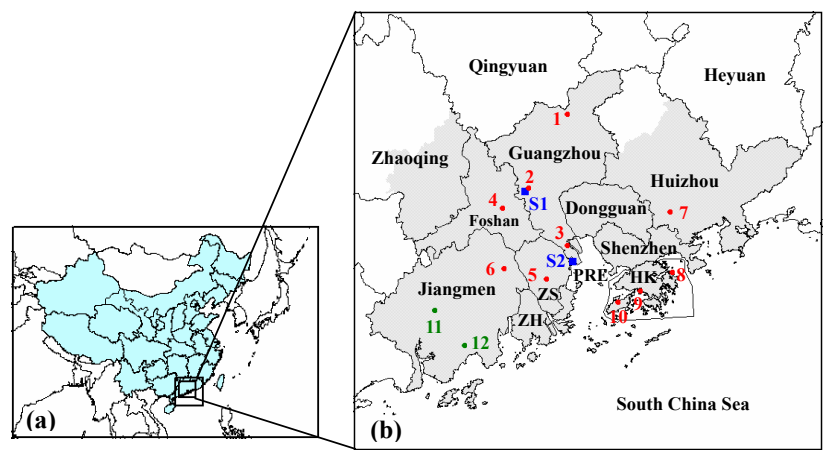

Fig. 1. (a) The 36-, 12-, and 4-km domains for CMAQ simulation; (b) locations of monitoring sites in the 4-km domain. Two super sites are labeled in blue: S1-GDEMC, S2-Xinken; the PRD air quality monitoring networks are labeled in red numbers: 1-Tianhu, 2-Luhu, 3-Wanqingsha, 4-Huijingcheng, 5-Zimaling, 6-Donghu, 7Jinguowan, 8-Tap Mun, 9-Tsuen Wan, and 10-Tung Chung; the sites labeled in green numbers (11-Kaiping and 12-Duanfen) are used to investigate the air quality in the southwestern inland and coastal areas of the PRD, although no observation data were collected at these sites during the PRIDE-PRD2004 campaign. The PRD region is the gray area on the map; the names of some subregions are abbreviated: ZS-Zhongshan, ZH-Zhuhai, HK-Hong Kong, PRE-Pearl River estuary.

CMAQ domain) and with 34 vertical layers. The one-way nesting simulations are performed with the following physics options: the mixed-phase microphysics, the Grell cumulus scheme, the medium-range forecast model's boundary layer scheme, the rapid radiative transfer model longwave scheme, and the Noah land-surface model. The National Centers for Environmental Protection (NCEP) $1^{\circ} \times 1^{\circ}$ global reanalysis data, the NCEP global surface and upper air observation data, and observations measured in the atmospheric boundary layer (ABL) during the PRIDE-PRD2004 campaign are used to prepare the initial and boundary conditions for the MM5 simulations. The four-dimensional data assimilation technique ("grid nudging") is used to nudge 3-D winds, temperature and humidity at six-hour intervals, and surface winds at three-hour intervals.

The gridded and speciated hourly emission inputs for CMAQ are prepared using the Sparse Matrix Operator Kernel Emissions (SMOKE) model (version 2.3, Houyoux et al., 2000). The TRACE-P anthropogenic emissions inventory (Streets et al., 2003) with $1^{\circ} \times 1^{\circ}$ resolution is used for the outer $36-\mathrm{km}$ domain. Inventory inputs (to SMOKE) of anthropogenic emissions for the inner domains are based on an inventory compiled by the Hong Kong Environmental Protection Department (P. Louie, personal communication, 2006), which has been applied in modeling studies such as Huang et al. (2005, 2006). Emission estimations in PRD area from several recent studies, including biomass burning emissions by Cao et al. (2005), vehicular emissions by Song and Xie (2006) and anthropogenic VOCs emissions by Liu et al. (2008a) are also included in the update of the inventory. In addition, the emissions are projected from the base year of original datasets to the year 2004 to include the impacts from the changes of economy, population and vehicle volume as well as other activity parameters relating to emissions. In this composite and high-resolution regional inventory, anthropogenic emissions of $\mathrm{NO}_{\mathrm{x}}, \mathrm{VOCs}, \mathrm{CO}, \mathrm{SO}_{2}, \mathrm{NH}_{3}$, and $\mathrm{PM}$ are reported in three major source categories: point sources (mainly power generation and industrial sources), mobile sources (on-road and off-road vehicles, marine traffic, and aircraft), and area sources (e.g., domestic and commercial fuel combustion, industrial processes, solvent evaporation loss, storage and transport of petroleum products, and agricultural activities). The biogenic VOC and NO emissions are estimated by applying the Biogenic Emissions Inventory System version 3.09 (BEIS 3.09, Vukovich and Pierce, 2002) with a Chinese plantation survey dataset (Pearl River Delta environmental protection planning committee, 2006). The default BEIS emission factors and the hourly meteorological fields from MM5 simulations are used.

As shown in Table 1, mobile sources and power generation point sources contribute about $47 \%$ and $39 \%$, respectively, of the total $\mathrm{NO}_{\mathrm{x}}$ emissions in the PRD, whereas mobile sources, evaporation losses of solvents and petroleum, and biogenic sources are the three largest contributors to VOC emissions, accounting for $38 \%, 24 \%$ and $23 \%$, respectively. Spatially, both $\mathrm{NO}_{\mathrm{x}}$ and VOC emissions are found to concentrate over the inland urban areas of Guangzhou, Foshan, and Dongguan; the coastal areas of Dongguan and Shenzhen; and the urban core of Hong Kong (Fig. 2).

\subsection{Model evaluation protocol}

Predicted meteorological fields (including winds, temperature, and humidity) are examined against the hourly observations obtained during October 2004 for each domain. Performance statistics for the MM5 simulations are calculated using the Metstat statistical analysis package (Emery et al., 2001).

The simulation of $\mathrm{O}_{3}$ formation during 4-31 October is evaluated against observations made at two super sites of the PRIDE-PRD2004 campaign (Zhang et al., 2008a) and measurements collected simultaneously at the ten regular surface sites of the PRD air quality monitoring network (see site locations in Fig. 1b). Note that the platform of the super site at Guangdong Provincial Environmental Monitoring Center (GDEMC) sits on the roof of a 17-story building, $\sim 50 \mathrm{~m}$ above the ground, in the urban center of Guangzhou City. The other super site of Xinken is a seaside rural site. The levels of $\mathrm{O}_{3}$ and $\mathrm{NO}_{\mathrm{x}}$ were measured by TECO commercial instruments TECO 49C and 42C, respectively, at the super sites and stations of PRD air quality monitoring network (Zhang et al., 2008b). Two kinds of measurement techniques for non-methane hydrocarbons (NMHCs) were adopted at the super sites. One was canister sampling followed by analysis 

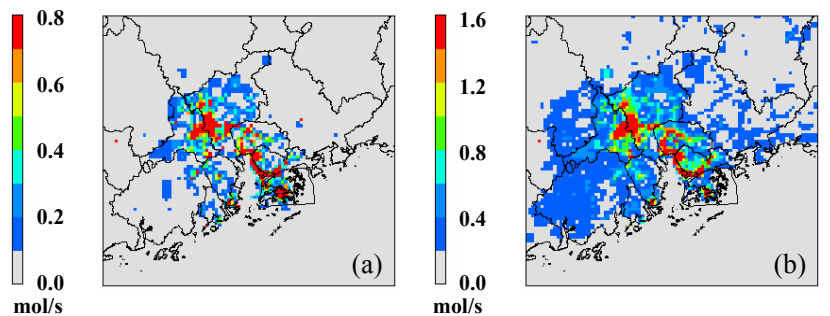

Fig. 2. $\mathrm{NO}_{\mathrm{x}}$ (a) and $\operatorname{VOC}$ (b) emissions in the 4-km grid at 12:00 local standard time (LST) on 16 October 2004.

using gas chromatography (GC) combined with mass spectrometry (MS) and flame ionization detection (FID) for C2C12 species (Liu et al., 2008b), and the other was on-line GC-FID for C3-C12 species (Wang et al., 2008a). The canister measurements usually collected three samples per day at GDEMC and two samples per day at Xinken during the entire campaign, whereas the on-line observations are only available in the second half of the month. The simulated concentrations of all NMHC-related species in the SAPRC99 mechanism are summed together for comparison with canister NMHCs observations, and $\mathrm{C} 2$ species are not included in the simulated values when those values are compared with the on-line NMHCs observations.

The performance is judged by statistical measures, including the correlation coefficient, normalized mean bias (NMB), and normalized mean error (NME), defined as

$\mathrm{NMB}=\frac{\sum_{i=1}^{N}\left(C_{i}^{s}-C_{i}^{o}\right)}{\sum_{i=1}^{N} C_{i}^{o}} \cdot 100 \%$,

$\mathrm{NME}=\frac{\sum_{i=1}^{N}\left|C_{i}^{s}-C_{i}^{o}\right|}{\sum_{i=1}^{N} C_{i}^{o}} \cdot 100 \%$,

where $C_{i}^{s}$ and $C_{i}^{o}$ represent simulated and observed concentrations at a same monitoring site for the same hour, respectively, and $\mathrm{N}$ is the total number of such data pairs of interest.

\subsection{Integrated process rate analysis}

Production of $\mathrm{O}_{3}$ is the net result of interactions of the various atmospheric processes involved (e.g., chemistry, transport, deposition). The integrated process rate (IPR) analysis implemented in the CMAQ model is used here to investigate the influences of major physical processes and the net effect of chemistry on model predictions. The IPR analysis calculates hourly contributions of gas-phase chemistry, horizontal transport (including advection and diffusion), vertical transport (including advection and diffusion), dry deposition, and
Table 1. Summary of annual emissions of $\mathrm{NO}_{\mathrm{x}}$ and VOCs by source category over the PRD in 2004 (kilotons/yr).

\begin{tabular}{lrr}
\hline Source category & $\mathrm{NO}_{\mathrm{x}}$ & $\mathrm{VOCs}$ \\
\hline Power generation point source & 294 & 34 \\
Mobile source & 349 & 545 \\
Industrial source & 52 & 20 \\
Domestic \& commercial fuel combustion source & 36 & 73 \\
Solvent \& petroleum evaporation source & 0 & 345 \\
Agriculture source \& others & 11 & 105 \\
Biogenic source* & 6 & 328 \\
Total & 748 & 1450 \\
\hline
\end{tabular}

* The annual biogenic emissions are estimated based on the mean emission amounts in the October, 2004.

some other processes (such as cloud processes, aerosol processes, and emissions) at each model grid cell. Details of IPR analysis can be found elsewhere (Jeffries and Tonnesen, 1994; Jang et al., 1995; Gipson, 1999). Recent applications of the IPR in CMAQ model have been reported by $\mathrm{Xu}$ et al. (2008), Yu et al. (2009), Gonçalves et al. (2009), Wang et al. (2009), and Zhang et al. (2009a, b).

For the IPR analysis, we first assess the roles of various atmospheric processes in $\mathrm{O}_{3}$ formation in $\mathrm{ABL}$ at the two super sites, GDEMC and Xinken, and at the Donghu station. The $\mathrm{O}_{3}$ pollution at GDEMC represents a typical situation in Guangzhou urban areas (source region), whereas that at Xinken, a rural site with less local emissions, reflects the influences of pollutants transported from upwind areas (Guangzhou and Dongguan under northerly winds; Shenzhen and Hong Kong under southerly winds). Donghu is an urban site in Jiangmen City, located $\sim 60 \mathrm{~km}$ downwind of the urban areas of Guangzhou and Foshan under northerly wind conditions. The maximum $\mathrm{O}_{3}$ levels were recorded at Donghu during the campaign. We then investigate the influences of different processes (precursor emissions, physical transport, and gas-phase chemistry) on the formation and evolution of regional $\mathrm{O}_{3}$ pollution over the PRD.

\subsection{Ozone production efficiency calculation}

Ozone production efficiency (OPE) is defined as the number of molecules of $\mathrm{O}_{3}$ formed per $\mathrm{NO}_{\mathrm{x}}$ removed from atmospheric ozone-forming oxidation cycles [i.e., $\left.P\left(\mathrm{O}_{3}\right) / P\left(\mathrm{NO}_{\mathrm{z}}\right)\right]$ (Seinfeld and Pandis, 2006). OPE is an important measure for determining the efficiency of the catalyst $\mathrm{NO}_{\mathrm{x}}$ in $\mathrm{O}_{3}$ formation and for indicating the $\mathrm{O}_{3}-\mathrm{VOC}-\mathrm{NO}_{\mathrm{x}}$ sensitivity under certain polluted conditions (Sillman, 1995; Sillman and He, 2002). In this work, OPE for the time range and spatial region of interest is estimated based on the IPR results, which provide the net chemical production of $\mathrm{O}_{3}$ and $\mathrm{NO}_{z}$ at each grid cell on an hourly basis [i.e., $P\left(\mathrm{O}_{3}\right)$ and $\left.P\left(\mathrm{NO}_{\mathrm{z}}\right)\right]$. 


\section{$2.5 O_{3}$ sensitivity testing}

Understanding of the non-linear relationship between $\mathrm{O}_{3}$ formation and its precursors is critical for the development of an effective $\mathrm{O}_{3}$ control strategy. We evaluate the $\mathrm{O}_{3}$ response to precursors by perturbing the domain-wide anthropogenic emissions of $\mathrm{NO}_{\mathrm{x}}$ and VOCs and then examining the resulting changes in $\mathrm{O}_{3}$ concentrations and $\mathrm{O}_{3}$ production rates. The perturbations of emissions include a $25 \%$ reduction in $\mathrm{NO}_{\mathrm{x}}$ emissions, a $25 \%$ reduction in VOC emissions, and a $25 \%$ reduction in both emissions. The reductions are only applied to the anthropogenic emission sources, no changes to biogenic emissions. Also, the reductions are linearly distributed across all $\mathrm{NO}_{\mathrm{x}}$ and/or VOC species and applied over all the time and space, at the same percentage of $25 \% \cdot \mathrm{O}_{3}$ sensitivity to precursors may vary with the magnitude of emission reductions; here, the $25 \%$ emission-reduction scenarios are used because this reduction level is more feasible and probable in real controls than $50 \%$ or higher reductions. Furthermore, we examine the influence of the photochemical age of air mass (indicated by the ratio of $\mathrm{NO}_{\mathrm{x}} / \mathrm{NO}_{\mathrm{y}}$ ) on the sensitivity of $\mathrm{O}_{3}$ formation to precursors.

\section{Results and discussions}

\subsection{Evaluation of model performance}

Simulated surface meteorological fields were examined against the surface hourly observations during the field campaign, and the MM5 model performance (shown in Table 2) is well within the typical range of meteorological modeling studies (Emery et al., 2001; Hanna and Yang, 2001).

Simulated $\mathrm{O}_{3}$ concentrations compare well against the observations at the two super sites and at other network sites (Table 3), with a correlation coefficient of 0.73 , NMB of $-5.4 \%$, and NME of $37.1 \%$, comparable to the performance of other CMAQ applications (Zhang et al., 2006; Gonçalves et al., 2009). The simulations reproduce the diurnal variations and magnitude of $\mathrm{O}_{3}$ reasonably well at most sites (Fig. 3), except at Tianhu, which is an upwind rural site. Comparisons of precursor concentrations (i.e., $\mathrm{NO}_{2}$ and NMHCs) at the monitoring sites further demonstrate that the $\mathrm{O}_{3}$ formation is captured reasonably well (and for the right reasons) over the domain and throughout the period (Table 3 , Figs. 4 and 5).

Note that the levels of peak $\mathrm{O}_{3}$ tend to be underpredicted at a few sites (e.g., Tianhu, Wanqingsha, and Zimaling, see Fig. 3). This may be related to several factors, such as the uncertainties in the precursor emissions and meteorological parameters. In the current inventory, compared with the data for PRD urban areas, the emission estimations over the suburban and rural areas of the PRD and the areas outside the PRD have higher uncertainties due to the limited source information available and fewer reported studies. For instance,
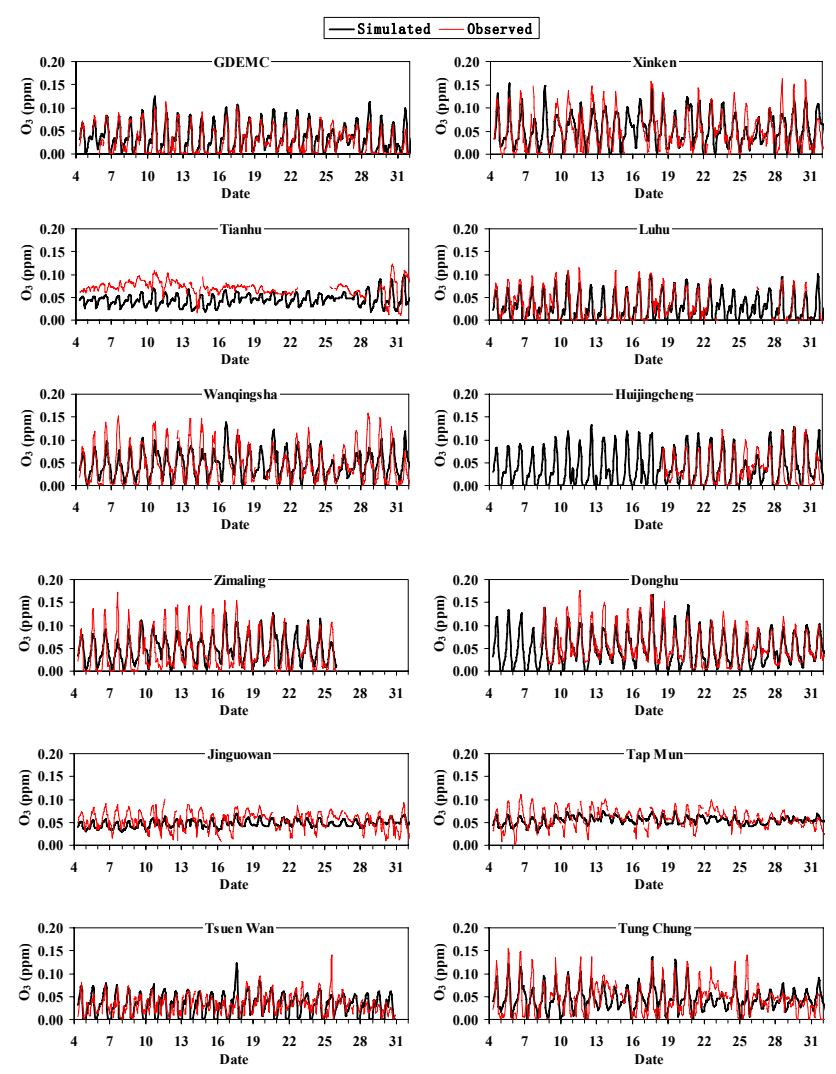

Fig. 3. Time series of simulated surface $\mathrm{O}_{3}$ against that observed at PRD monitoring sites during 4-31 October 2004.

the evolution of observed $\mathrm{O}_{3}$ at Tianhu, a rural site in the far north of Guangzhou, had an elevated background level of $\mathrm{O}_{3}$ ranging from 60 to $70 \mathrm{ppb}$ during the campaign and was less affected by local photochemical production (except during 29-31 October). Considering the prevailing northerly winds in October, the underestimation of $\mathrm{O}_{3}$ at Tianhu may be caused by the uncertainties in emissions in northern rural areas of Guangzhou and distant northern areas such as Qingyuan. The overestimation of surface wind speeds by MM5 (see Table 2) may result in more transport and less accumulation of $\mathrm{O}_{3}$ and its precursors, which is a probable cause of the underestimated $\mathrm{O}_{3}$ peaks at some other sites as well.

The measurements of $\mathrm{NO}_{\mathrm{x}}$ and VOCs are greatly influenced by local emissions. October is harvest season for agricultural crops in PRD and biomass burning in open fields was significant and was observed during the campaign. Although the emissions by burning crop residues have been included in the inventory, an exact estimation of precursor emissions is difficult due to the limited information on the details of burning events (i.e., the place and duration of biomass burning, amount of burned crop residues). This may result in the uncertainties in the simulated precursors concentrations and $\mathrm{O}_{3}$ levels as well, especially at rural sites (e.g., Tianhu, 

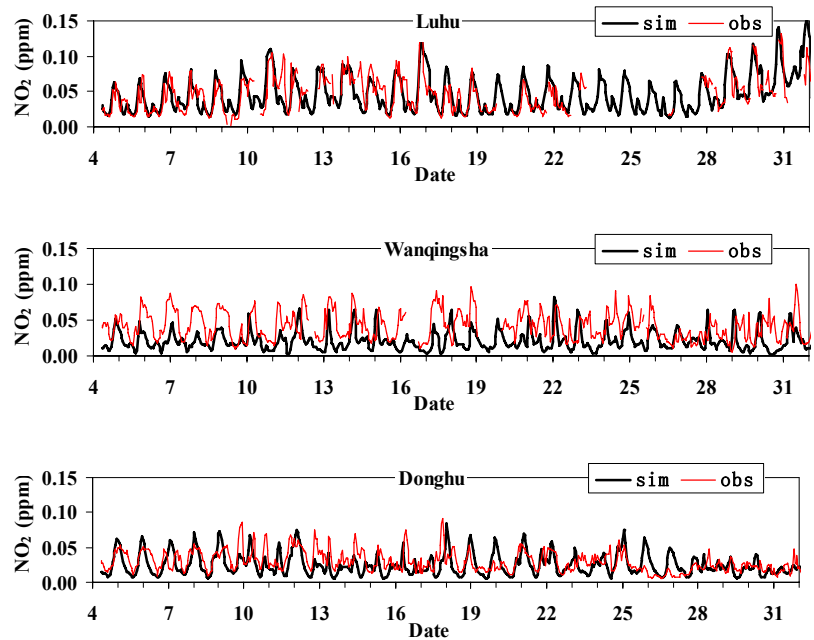

Fig. 4. Comparison of observed and simulated $\mathrm{NO}_{2}$ at the Luhu, Wanqingsha, and Donghu sites.
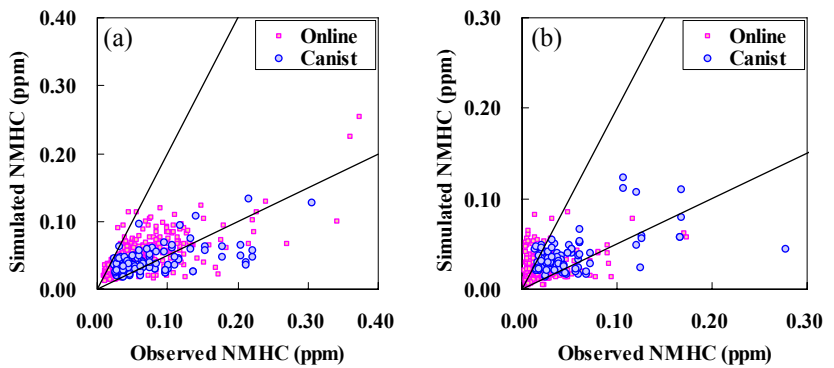

Fig. 5. Scatter plot of observed and simulated NHMC at (a) GDEMC and (b) Xinken. The 1:2 and 2:1 lines are also included.

Wanqingsha and Xinken). Another significant uncertainty in estimating VOCs emissions comes from the lack of local representative emission factors of VOCs from industrial and domestic solvent use, which also accounts for the underprediction of ambient VOCs concentrations, especially for aromatic levels. Further nighttime vertical diffusions are not easily simulated by current mesoscale meteorological models, especially over the complex topography and land use in PRD. This may be a reason for higher deviations of precursor levels between model results and measurements during night and early morning.

In addition, studies have revealed that molybdenum converter (equipped in the TECO $42 \mathrm{C}$ chemiluminescence $\mathrm{NO}_{\mathrm{x}}$ analyzers as used in the campaign) reduces not only $\mathrm{NO}_{2}$ but also other nitrogen-containing compounds (e.g., nitric acid, peroxyacetyl nitrate and other organic nitrates) to $\mathrm{NO}$, hence can cause the $\mathrm{NO}_{\mathrm{x}}$ analyzer overestimating the real $\mathrm{NO}_{2}$ concentrations (Steinbacher et al., 2007). Apparently this overestimation of real $\mathrm{NO}_{2}$ concentrations by measurements accounts for, at least in part, the low bias of the $\mathrm{NO}_{2}$ performance (Table 3).
Table 2. Performance statistics of the MM5-simulated meteorological variables against surface observations during 1-31 October 2004.

\begin{tabular}{llrrr}
\hline $\begin{array}{l}\text { Meteorological } \\
\text { variable }\end{array}$ & $\begin{array}{l}\text { Statistical } \\
\text { parameter }\end{array}$ & D1* & D2* & D3* \\
\hline Surface wind & RMSE** $(\mathrm{m} / \mathrm{s})$ & 2.07 & 2.06 & 1.64 \\
speed & Bias (m/s) & 0.32 & 0.89 & 0.27 \\
& IOA*** & 0.79 & 0.65 & 0.66 \\
Surface wind & Gross Error (deg.) & 39.49 & 42.15 & 38.11 \\
direction & Bias (deg.) & 3.47 & 2.47 & 0.56 \\
Surface & Gross Error (K) & 2.27 & 2.09 & 1.98 \\
temperature & Bias (K) & -0.90 & -0.88 & 0.39 \\
& IOA & 0.97 & 0.90 & 0.85 \\
Surface & Gross Error (g/kg) & 1.13 & 1.64 & 1.62 \\
humidity & Bias (g/kg) & -0.50 & -1.30 & -1.24 \\
& IOA & 0.94 & 0.78 & 0.64 \\
\hline
\end{tabular}

* D1, D2 and D3 stand for the domains with $36 \mathrm{~km}, 12 \mathrm{~km}$ and $4 \mathrm{~km}$ horizontal resolution, respectively.

** RMSE stands for the root mean square error.

*** IOA stands for the index of agreement (Emery et al., 2001).

Table 3. CMAQ performance statistics for the simulated hourly concentrations of surface $\mathrm{O}_{3}, \mathrm{NO}, \mathrm{NO}_{2}$ and $\mathrm{NHMC}$ against observations over the PRD during 4-31 October 2004.

\begin{tabular}{lrrrr}
\hline Species & $\begin{array}{r}\text { Number of } \\
\text { data pairs }\end{array}$ & $\begin{array}{r}\text { Correlation } \\
\text { coefficient }\end{array}$ & $\begin{array}{r}\mathrm{NMB}^{*} \\
(\%)\end{array}$ & $\begin{array}{r}\mathrm{NME}^{*} \\
(\%)\end{array}$ \\
\hline $\mathrm{O}_{3}$ & 6856 & 0.73 & -5.4 & 37.1 \\
$\mathrm{NO}$ & 4591 & 0.54 & -69.6 & 86.0 \\
$\mathrm{NO}_{2}$ & 4706 & 0.52 & -26.8 & 52.1 \\
$\mathrm{NMHC}$ & 759 & 0.66 & -24.2 & 47.7 \\
\hline
\end{tabular}

* NMB stands for normalized mean bias; NME stands for normalized mean error.

The modeled and observed $\mathrm{NO}$ are reasonably correlated with a correlation coefficient of 0.54 , similar to that of $\mathrm{NO}_{2}$ (see Table 3). Note that most of the NO low biases were for the measured NO peaks during the night time and the early morning rush hour (not shown). This may indicate that the $\mathrm{NO}_{\mathrm{x}}$ emissions were under-estimated at those time periods. However, the low biases can also be explained by the mismatching of modeled volume concentrations in a 4-km grid cell with observations which were largely impacted by local primary emissions under stable boundary layer conditions.

\subsection{Regional spatiotemporal evolution of surface ozone}

Both the CMAQ simulation and air quality measurements demonstrate that the PRD experienced serious photochemical smog pollution at the regional scale during the campaign (Fig. 3). The simulated monthly average distribution 
indicates that elevated levels of surface $\mathrm{O}_{3}$ usually occurred in the western and southern PRD. As shown in Fig. 6, areas with $\mathrm{O}_{3}$ higher than $0.090 \mathrm{ppm}$ include southern Foshan, Jiangmen, Zhongshan, the PRE and surrounding areas, and the southwestern coastal area. Regional $\mathrm{O}_{3}$ pollution was also recorded at stations located in the western PRD and around the PRE, such as Donghu, Zimaling, Wanqingsha, Xinken, and Tung Chung, where the $\mathrm{O}_{3}$ nonattainment (i.e. hourly $\mathrm{O}_{3}$ concentration exceeding the national ozone air quality standard of $200 \mu \mathrm{g} / \mathrm{m}^{3}$ or $\sim 0.093 \mathrm{ppm}$ ) days accounted for $88 \%, 95 \%, 77 \%, 88 \%$, and $61 \%$ of valid observation days during the campaign, respectively. The maximum hourly $\mathrm{O}_{3}$ concentration of $0.179 \mathrm{ppm}$ was measured at Donghu station (Zhang et al., 2008b). Although no surface observations of $\mathrm{O}_{3}$ concentrations were conducted in central and western Jiangmen during the campaign, aircraft measurements in the ABL reported average $\mathrm{O}_{3}$ levels of around $0.080 \mathrm{ppm}$ and a maximum $\mathrm{O}_{3}$ value of $0.101 \mathrm{ppm}$ over Kaiping in the afternoon (close to the levels in Zhongshan, but higher than those in Foshan and Huizhou) (Wang et al., 2008b), suggesting the occurrence of $\mathrm{O}_{3}$ pollution in the rural western PRD where the local precursor emissions are low.

The formation and distribution of $\mathrm{O}_{3}$ pollution over the PRD is greatly influenced by synoptic weather conditions and local circulations. During the campaign, a high-pressure system dominated over the PRD and resulted in light-tomoderate northerly or northeasterly synoptic winds. Three cold air masses from the north intruded into the PRD on 1, 17, and 25 October. After the influence of cold air weakened, both meteorological observations and simulated results showed the evolution of sea-land breezes in the southern PRD. Under weak synoptic conditions, northeasterly/northerly/easterly winds were dominant over the PRD from early morning to midday, and southerly or southeasterly sea breezes usually began in afternoon and ended around midnight in the southern PRD (Fan et al., 2008).

Based on the influences of the different near-ground flow patterns, we summarize three evolution patterns of simulated surface $\mathrm{O}_{3}$ over the PRD during the studied month. In the first pattern, named as " $\mathrm{O}_{3}$-South", the flows in lower layers were characterized by northerly or northeasterly winds prevailing over the PRD during the whole day due to moderate or strong synoptic forcing resulting from the intrusion of northern cold air. Elevated $\mathrm{O}_{3}$ during mid-afternoons was usually distributed over southern or southwestern inland and coastal regions, as well as the PRE area. At dusk, $\mathrm{O}_{3}$ concentrations in the urban areas of Guangzhou, Foshan, Shenzhen, and Hong Kong dropped to low levels due to the decrease in photochemical production and the removal of $\mathrm{O}_{3}$ by $\mathrm{NO}$ titration and dry deposition, while continuous transport by northerly winds moved the $\mathrm{O}_{3}$ plume to the southern water area (e.g. Fig. 7a).

The other two patterns occurred when synoptic winds were weak and sea-land breezes showed significant influence on

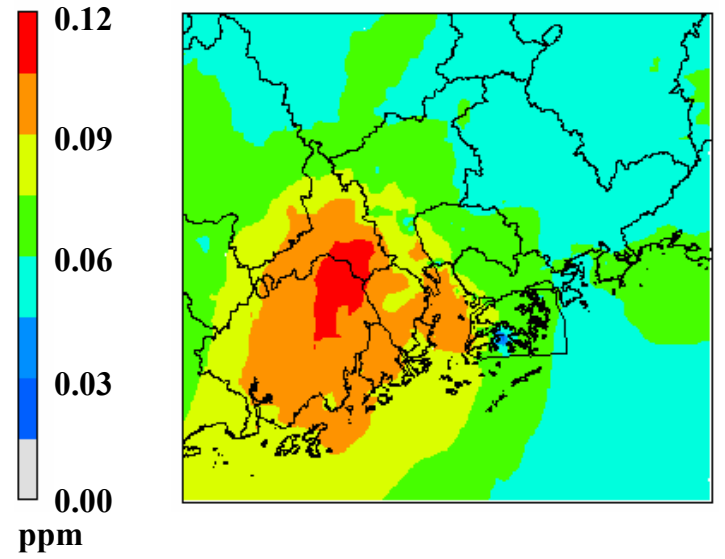

Fig. 6. Average hourly simulated surface $\mathrm{O}_{3}$ at 15:00 LST during October 2004.

the transport of air pollutants. Weak synoptic winds and stagnant conditions usually resulted in more severe photochemical pollution in the PRD. In the second pattern, named as "O $\mathrm{O}_{3}$-Southwest", northeasterly winds were dominant in the daytime over the PRD. Daytime elevated $\mathrm{O}_{3}$ was mainly distributed in the southwestern inland regions, PRE, and southern coastal areas (e.g. Fig. 7b). Because a southeasterly sea breeze developed along the coastal areas and strengthened gradually during the afternoon and at dusk, transport of the $\mathrm{O}_{3}$ plume to the southern water area was delayed, and $\mathrm{O}_{3}$ remained at high levels in the southern rural land areas of Jiangmen and Guangzhou even after sunset. In the third pattern, named as " $\mathrm{O}_{3}$-West", the easterly winds prevailed in lower layers during the daytime over most areas, and elevated $\mathrm{O}_{3}$ usually occurred in the western PRD in the afternoon. In this pattern, Jiangmen experienced a relatively light $\mathrm{O}_{3}$ pollution compared with the episodes on $\mathrm{O}_{3}$-Southwest days, and high levels of $\mathrm{O}_{3}$ were seldom found along the southern coastal area except for the PRE (e.g. Fig. 7c).

We group all days during 4-31 October into the aforementioned three patterns (Table 4). The classification of pollution days reflects the influence of the interaction between synoptic forcing and local circulation on the evolution of $\mathrm{O}_{3}$ pollution over the PRD during the campaign.

\subsection{Process analysis of $\mathrm{O}_{3}$ formation}

Here, 16-22 October is used for the IPR analysis because the PRD experienced all three $\mathrm{O}_{3}$ pollution patterns during this period (see Table 4), and the CMAQ simulation shows good performance at most sites on these days. The observed maximum height of the daytime ABL was about $1200 \mathrm{~m}$ during the campaign (Fan et al., 2008), corresponding to the lowest seven layers in the CMAQ simulation. Therefore, our process analysis mainly focuses on the IPR results from layers 1 to 7 . 

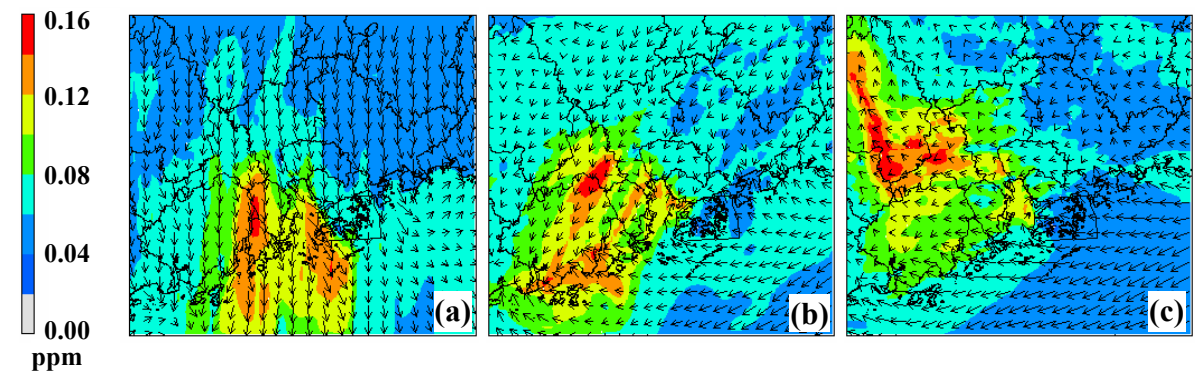

Fig. 7. Simulated surface $\mathrm{O}_{3}$ concentrations superimposed with the wind fields at 15:00 LST on (a) 19 October, (b) 16 October, and (c) 29 October, taken as examples of the three $\mathrm{O}_{3}$ evolution patterns, respectively.

Table 4. Classification of $\mathrm{O}_{3}$ pollution days into three evolution patterns in the PRD during 4-31 October 2004.

\begin{tabular}{lll}
\hline No. & Pattern & Date \\
\hline 1 & $\mathrm{O}_{3}$-South & $4,5,8,18,19,25,26$ \\
2 & $\mathrm{O}_{3}$-Southwest & $6,7,9,10,11,12,14,15,16,17,20,24,27$ \\
3 & $\mathrm{O}_{3}$-West & $13,21,22,23,28,29,30,31$ \\
\hline
\end{tabular}

\subsubsection{Process analysis at the selected site locations}

Figures 8 and 9 reveal the different roles of atmospheric processes in the evolution of $\mathrm{O}_{3}$ at the grid cells of the GDEMC, Xinken, and Donghu sites. In the lower layers of the urban GDEMC site, gas-phase chemistry exhibited a significant consumption of $\mathrm{O}_{3}$ during the whole day (especially during traffic rush hours) due to $\mathrm{O}_{3}$ titration by high $\mathrm{NO}_{\mathrm{x}}$ emissions, whereas horizontal and vertical transports were the main contributors to compensate for the chemical loss and to enhance the $\mathrm{O}_{3}$ levels during the daytime (Fig. 8a). During the buildup of daytime maximum $\mathrm{O}_{3}$ in the ABL from 09:00 to 15:00 local standard time (LST), the top chemical contributions occurred in the layers 5-7 (150-1000 $\mathrm{m}$ above ground level a.g.l.); the produced $\mathrm{O}_{3}$ was then horizontally transported to downwind areas and vertically transported to lower layers to balance the $\mathrm{O}_{3}$ removal by $\mathrm{NO}$ titration and dry deposition (Fig. 9a).

At the rural Xinken site, vertical transport contributed mainly to the $\mathrm{O}_{3}$ levels and was then decreased on a similar magnitude by horizontal transport during the daytime (Fig. 8b). Such influences of transport processes may be associated with the circulations of sea-land breezes over the PRE. The analysis of the simulated 3-D air flows showed that local air circulations often occurred at Xinken and were characterized by downdraft in the upper layers and divergence in the lower layers (Detailed discussion of this issue is presented in another manuscript in preparation by Zhou et al., 2009: land-sea breezes over Pearl River Estuary and their impact on local air quality in October 2004). Gas-phase

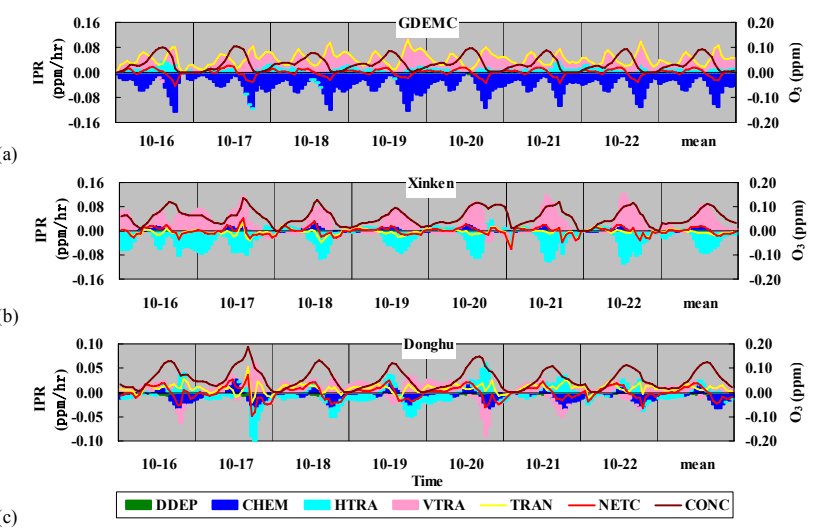

Fig. 8. Daily variations of $\mathrm{O}_{3}$ concentration and hourly $\mathrm{O}_{3}$ change rates due to various atmospheric processes in the lowest three layers (0-80 m a.g.1.) at (a) GDEMC, (b) Xinken, and (c) Donghu from 16-22 October 2004. (VTRA: vertical transport, the net effect of vertical advection and diffusion; HTRA: horizontal transport, the net effect of horizontal advection and diffusion; TRAN: transport, the net effect of VTRA and HTRA; DDEP: dry deposition; CHEM: gas-phase chemistry; NETC: the net change of hourly $\mathrm{O}_{3}$ due to all atmospheric processes; CONC: instantaneous $\mathrm{O}_{3}$ concentration at the end of each hour).

chemistry was also an important contributor to daytime $\mathrm{O}_{3}$ enhancement, characterized by more $\mathrm{O}_{3}$ production in lower layers (Fig. 9b).

Among the three sites (GDEMC, Xinken, and Donghu) shown in Fig. 9, Donghu experienced the maximum increase of $\mathrm{O}_{3}$ concentration in the ABL from 09:00 (0.046 ppm) to 15:00 LST (0.121 ppm) (Fig. 9c). Chemical production dominated the $\mathrm{O}_{3}$ enhancement, especially in upper layers (layers 3-7). In lower layers, although the influences of horizontal and vertical transports exhibited day-to-day variations due to different meteorological conditions, the net effects of transport mainly showed a positive contribution to near-ground $\mathrm{O}_{3}$ in most hours of a day (Fig. 8c). 

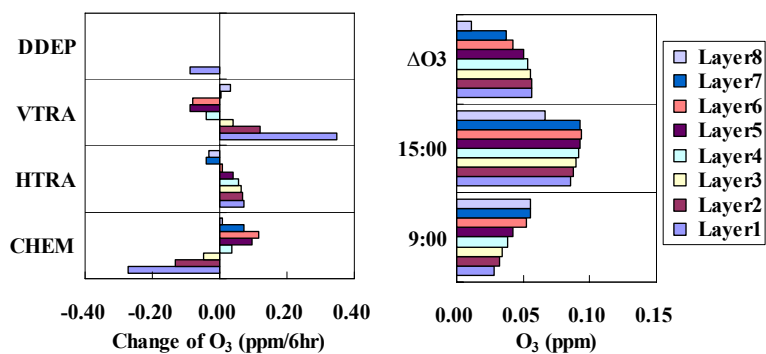

(a)

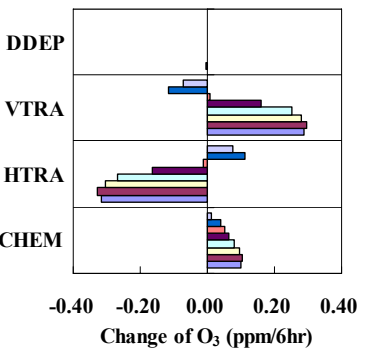

(b)

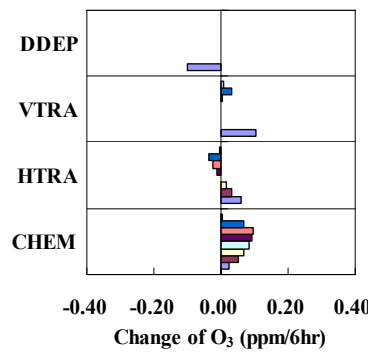

(c)
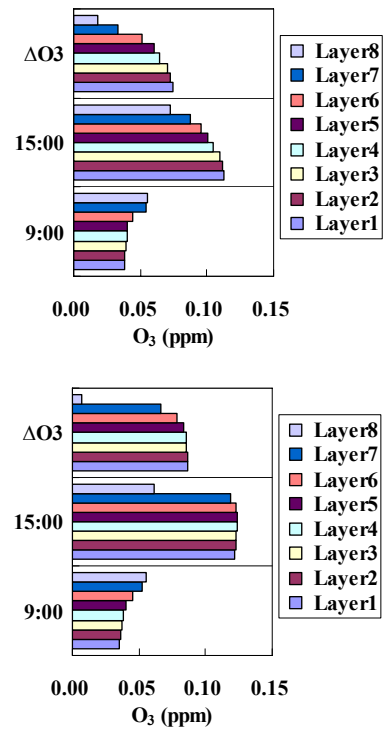

Fig. 9. $\mathrm{O}_{3}$ change rates due to various atmospheric processes for layers 1 to 8 (left) and evolution of $\mathrm{O}_{3}$ vertical profiles (right) at (a) GDEMC, (b) Xinken, and (c) Donghu from 09:00 to 15:00 LST averaged for 16-22 October 2004. (VTRA: vertical transport, the net effect of vertical advection and diffusion; HTRA: horizontal transport, the net effect of horizontal advection and diffusion; DDEP: dry deposition; CHEM: gas-phase chemistry; $\triangle \mathrm{O} 3$ : the change of $\mathrm{O}_{3}$ concentrations from 09:00 to 15:00 LST).

Dry deposition was a sink for surface $\mathrm{O}_{3}$ at GDEMC and Donghu, but showed weaker effects at Xinken because water covers more than $90 \%$ of the grid cell in which this coastal site is located. The wet deposition and cloud processes were also negligible due to the low cloudiness and the absence of precipitation during this period.

In many $\mathrm{O}_{3}$ chemistry studies, the total oxidant $\mathrm{O}_{\mathrm{x}}$ (estimated by $\mathrm{O}_{3}+\mathrm{NO}_{2}$ ) is frequently used in data analysis because $\mathrm{O}_{\mathrm{x}}$ is not affected by the rapid photodissociation of $\mathrm{NO}_{2}$ and the titration of $\mathrm{O}_{3}$ with $\mathrm{NO}$, being a better measure of the real photochemical production of ozone (Chou et al., 2006; Zhang et al., 2008b). In layers 1-7, the overall average $\mathrm{O}_{\mathrm{x}}$ chemical productions at GDEMC, Donghu, and Xinken were $0.102 \mathrm{ppm} / 6 \mathrm{~h}, 0.082 \mathrm{ppm} / 6 \mathrm{~h}$, and $0.048 \mathrm{ppm} / 6 \mathrm{~h}$, respectively, indicating that the photochemical oxidant production rate in the urban area was greater than that in the rural region, similar to findings from a study of $\mathrm{O}_{3}$ pollution

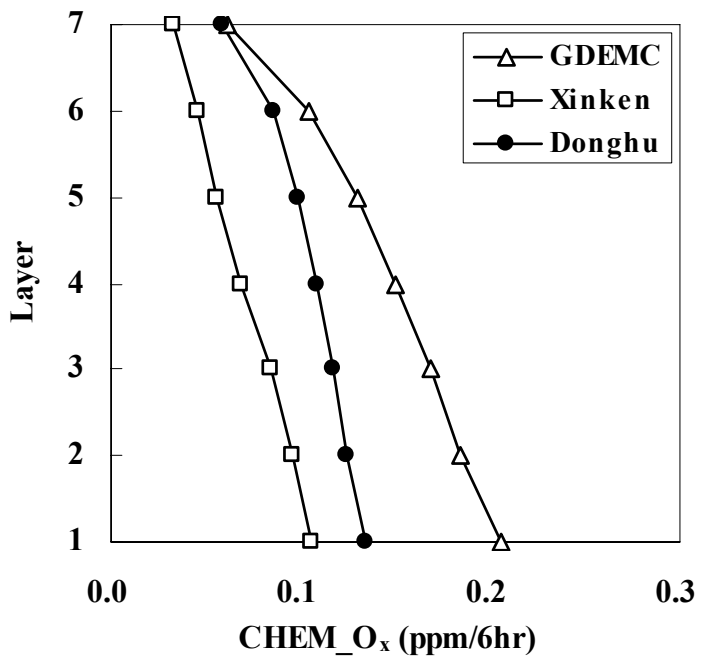

Fig. 10. Changes in $\mathrm{O}_{\mathrm{x}}$ due to gas-phase chemistry at GDEMC, Xinken, and Donghu in the ABL (for layers 1 to 7) from 09:00 to 15:00 LST averaged for 16-22 October $2004\left(\mathrm{O}_{\mathrm{x}}\right.$ is estimated by $\mathrm{O}_{3}+\mathrm{NO}_{2}$ )

in Taipei (Chou et al., 2006). As shown in Fig. 10, an interesting phenomenon is that the vertical profiles of $\mathrm{O}_{\mathrm{x}}$ changes derived from gas-phase chemistry and accumulated from 09:00 to 15:00 LST were similar at GDEMC, Xinken, and Donghu $\left(\mathrm{O}_{\mathrm{x}}\right.$ chemical production decreases with height), in contrast to the significant differences among the vertical profiles of $\mathrm{O}_{3}$ chemical formation illustrated in Fig. 9.

As pollutants are generally well mixed in the ABL during daytime conditions, we summarize the process budgets integrated over the depth of the daytime ABL (corresponding to the vertical range of layers 1 to 7) in Table 5. In the ABL, the process contributions to daytime maximum $\mathrm{O}_{3}$ at GDEMC, Xinken, and Donghu share common features regardless of their urban vs. rural locations: (1) although horizontal and vertical transports accounted for a considerable portion of process budgets, the net effects of transport processes exhibited negative contributions to the build-up of maximum $\mathrm{O}_{3}$, and (2) gas-phase chemistry dominated the $\mathrm{O}_{3}$ enhancement from morning to mid-afternoon, when $\mathrm{O}_{3}$ concentrations usually reached the maximum level of the day.

\subsubsection{Process analysis applied to regional $\mathrm{O}_{3}$ pollution}

In this section, the process analysis focuses on the whole PRD region during its daytime $\mathrm{O}_{3}$ build-up in the $A B L$ from 09:00 to 15:00 LST. On 16, 19, and 22 October (characterized by different near-ground flow conditions and $\mathrm{O}_{3}$ pollution patterns; refer to Table 4), gas-phase chemistry played a dominant role in the $\mathrm{O}_{3}$ enhancements over most of the area of the PRD, especially in the southern and western PRD where elevated $\mathrm{O}_{3}$ was distributed around mid-afternoon. In contrast, the transport process (the sum of horizontal and 
Table 5. Summary of the average accumulated contributions of each process to $\mathrm{O}_{3}$ formation over the depth of layers 1 to 7 for the period of 09:00 to 15:00 LST during 16-22 October 2004 at the GDEMC, Xinken, and Donghu sites (ppm/6 h).

\begin{tabular}{lrrrrr}
\hline Site & CHEM $^{*}$ & HTRA & VTRA & DDEP & NETC \\
\hline GDEMC & 0.072 & 0.004 & -0.030 & -0.002 & 0.044 \\
Xinken & 0.055 & -0.031 & 0.025 & 0.000 & 0.049 \\
Donghu & 0.082 & -0.021 & 0.016 & -0.002 & 0.075 \\
\hline
\end{tabular}

* CHEM: gas-phase chemistry; HTRA: horizontal transport, the net effect of horizontal advection and diffusion; VTRA: vertical transport, the net effect of vertical advection and diffusion; DDEP: dry deposition; NETC: net change due to all processes.

vertical transports) exhibited less influence on the regional scale, except in isolated areas, where the large power plants or the busy harbors were located and intensive $\mathrm{NO}_{\mathrm{x}}$ emissions resulted in strong $\mathrm{O}_{3}$ titration (Fig. 11). The dominant contribution of chemical production not only occurred on the days with different near-ground flow conditions, but also over the areas with different emission strengths (i.e., urban vs. rural).

The lower precursor emissions in Jiangmen and southwestern coastal areas (Fig. 2) indicate that the transport process might play an important role in maintaining the necessary levels of precursors involved in the elevated $\mathrm{O}_{3}$ chemical production there. The regional distribution of $\mathrm{NO}_{\mathrm{x}}$ contributed by the transport process, integrated over the depth of layers 1 to 7 and accumulated from late afternoon (17:00 LST) to the next morning (09:00 LST), is used to reflect the redistribution of $\mathrm{NO}_{\mathrm{x}}$ from the source regions to the whole PRD (Fig. 12). The IPR results show that the transport process functions as a sink of $\mathrm{NO}_{\mathrm{x}}$ in areas with intensive $\mathrm{NO}_{\mathrm{x}}$ emissions (such as in urban areas of Guangzhou, Dongguan, Shenzhen, and Hong Kong), but as the dominant source of $\mathrm{NO}_{\mathrm{x}}$ over the southern or southwestern PRD (especially in Jiangmen and the PRE), even if the accumulated time range is extended to 15:00 LST of the next afternoon.

The flow conditions influence the transport and redistribution of $\mathrm{NO}_{\mathrm{x}}$ during the night and next morning (Fig. 12). From late afternoon to midnight on 15 and 21 October, southeasterly sea breezes developed and prevailed in the southern part of the PRD, and wind convergence appeared over Panyu, Jiangmen, and Zhongshan (Fan et al., 2008), which mixed the $\mathrm{NO}_{\mathrm{x}}$ plumes from northern source areas (i.e., urban Guangzhou and Foshan) with plumes from southern areas (i.e., Dongguan, Shenzhen, and Hong Kong) inside the PRD; this hindered the transport of $\mathrm{NO}_{\mathrm{x}}$ outside the PRD. After midnight, northerly or northeasterly wind again prevailed over the $\mathrm{PRD}$, and the delayed $\mathrm{NO}_{\mathrm{x}}$ plume was transported to the south and west, providing the majority of $\mathrm{NO}_{\mathrm{x}}$ involved in $\mathrm{O}_{3}$ enhancement by the daytime photochemical

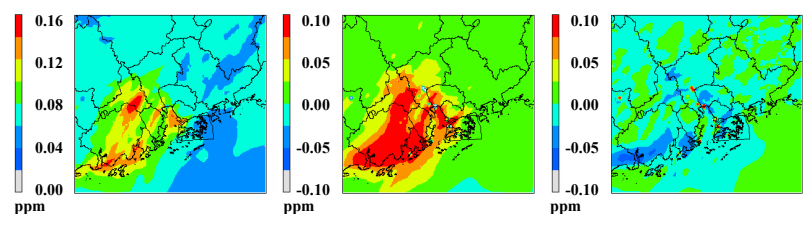

(a)
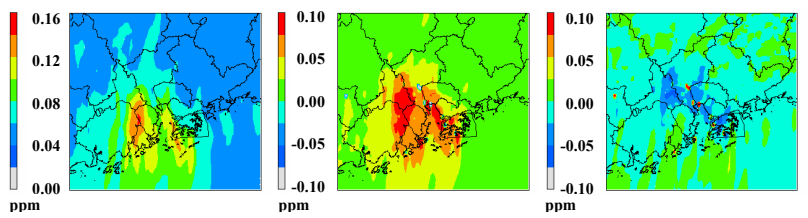

(b)
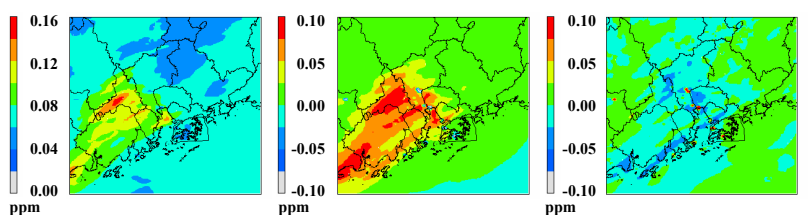

(c)

Fig. 11. Regional distributions of $\mathrm{O}_{3}$ concentrations at 15:00 LST (left) and the accumulated contributions of gas-phase chemistry (center) and physical transport (right) from 09:00 to 15:00 LST over the depth of layers 1 to 7 on (a) 16 October, (b) 19 October, and (c) 22 October 2004.

process in Jiangmen and southwestern coastal areas. The transport of $\mathrm{NO}_{\mathrm{x}}$ from the late afternoon of 18 October to the morning of 19 October was mainly controlled by northerly winds and was not affected by the sea breeze, which resulted in less $\mathrm{NO}_{\mathrm{x}}$ accumulation inside the PRD than what happened on 15-16 and 21-22 October.

The above process analysis not only exhibits the redistributions of precursors from night to the next morning, but also reveals the significance of $\mathrm{O}_{3}$ chemical production on a large regional scale in the daytime under such close interactions among the precursor emissions, physical transport, and photochemical process.

\subsection{Ozone production efficiency}

As illustrated in Fig. 13, OPE shows significant spatial variations over the PRD. The calculated OPEs are $2-8$ in most regions of the middle and western PRD, corresponding to the areas of high $\mathrm{O}_{3}$ chemical production (Fig. 11a). Less efficiency (i.e., OPE values of 1-5) is shown in the urban areas of Guangzhou, Foshan, Shenzhen, and Hong Kong, characterized by intensive $\mathrm{NO}_{\mathrm{x}}$ emissions, as well as downwind areas of the urban plumes under prevailing northeasterly flow. In contrast, high OPEs (larger than 11) are shown over upwind or rural areas with less $\mathrm{NO}_{\mathrm{x}}$ source emissions (e.g., Huizhou, Zhaoqing, and Qingyuan).

For the period of 16-22 October, the average OPE values during 09:00-15:00 LST were 3.6 (2.9-4.0) at GDEMC, 

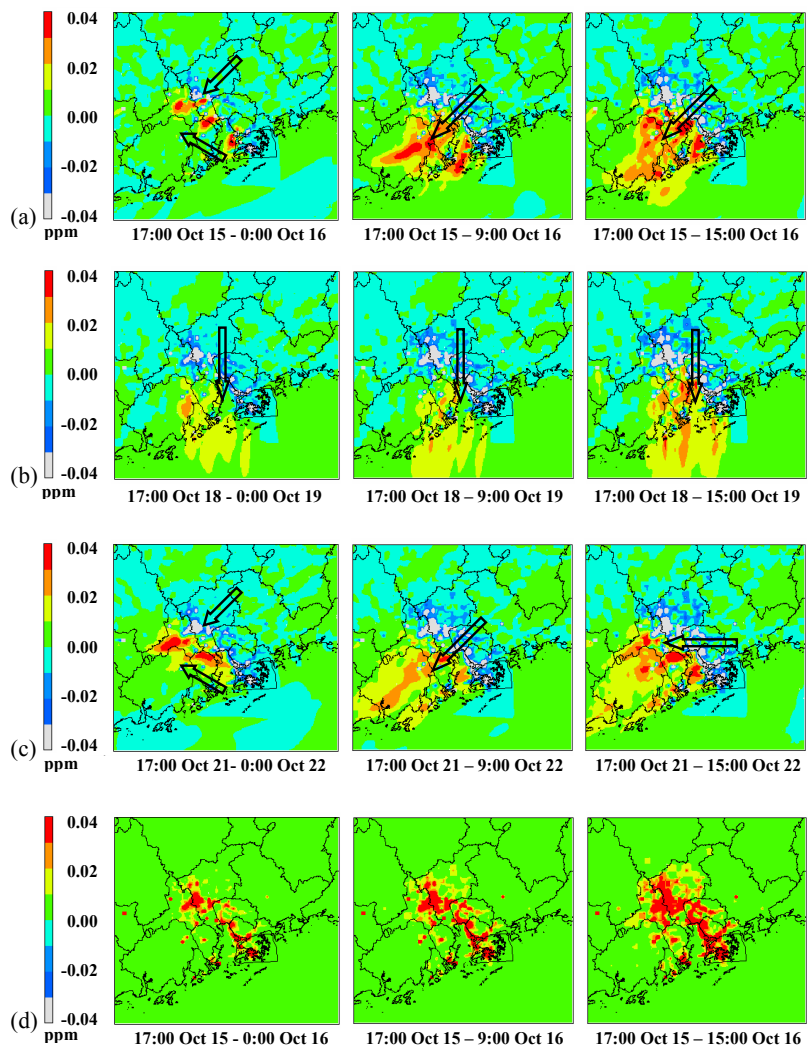

Fig. 12. (a), (b) and (c) The accumulated contributions to $\mathrm{NO}_{\mathrm{x}}$ by the transport process over the depth of layers 1 to 7 from 17:00 to 00:00 (left), 09:00 (center), and 15:00 LST (right) of the next day. The arrows show the near-ground dominant wind directions during the periods of 17:00-24:00 LST (left), 00:00-09:00 LST (center), and 09:00-15:00 LST (right). (d) The accumulated $\mathrm{NO}_{\mathrm{x}}$ emissions in the same time range and vertical layers during 15-16 October are shown for comparison.

$4.9(4.2-5.9)$ at Xinken, and $5.0(3.3-7.3)$ at Donghu. $\mathrm{NO}_{\mathrm{x}}$ exhibits lower catalysis efficiency at the urban GDEMC site because of intensive local $\mathrm{NO}_{\mathrm{x}}$ emissions by vehicles and industrial activities. For the rural Xinken site, despite lower local emissions, the significant $\mathrm{NO}_{\mathrm{x}}$ sources in neighboring areas (such as power plants along the southern coast of Dongguan and intense $\mathrm{NO}_{\mathrm{x}}$ emissions in the western coastal area of Shenzhen and in Hong Kong) provide $\mathrm{NO}_{\mathrm{x}}$ for local photochemical reactions, resulting in a similar level of OPE as that found at Donghu (urban site). The simulated OPEs at the super sites are comparable to those observed in urban Beijing, ranging from 3.9 to 9.7 (Chou et al., 2009), and those observed or modeled in US cities (Nashville, 2.5-4.0, Nunnermacker et al., 1998; New York City, 2.2-4.2, Kleinman et al., 2000) and in the Mexico City Metropolitan Area (4-10, Lei et al., 2007).

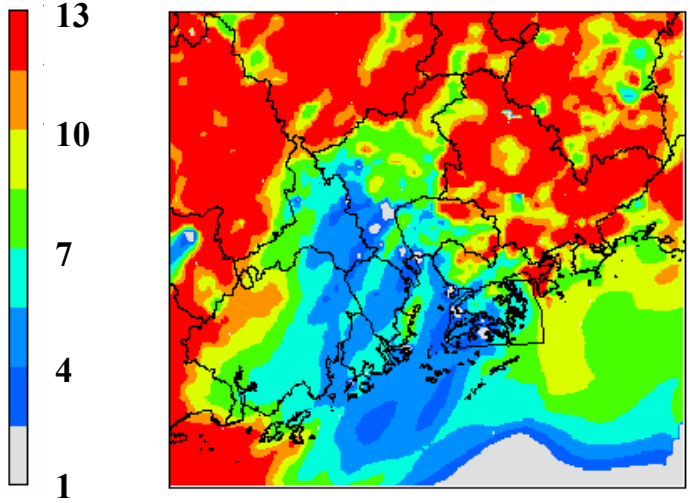

Fig. 13. Regional distribution of OPE calculated based on the overall chemical production of $\mathrm{O}_{3}$ and $\mathrm{NO}_{\mathrm{Z}}$ over the lowest seven layers from 09:00 to 15:00 LST on 16 October 2004.

\subsection{Sensitivity of $\mathrm{O}_{3}$ to precursors}

In this section, we first examine the response of surface $\mathrm{O}_{3}$ to precursor emission reductions, averaged over 12:0017:00 LST from 16 to 22 October (Fig. 14). Over the central inland PRD and the PRE and surrounding coastal areas (i.e., the region marked by the red ellipse in Fig. 14), $\mathrm{O}_{3}$ levels decrease (by $0.006-0.019 \mathrm{ppm}$ ) with the reduction of only VOC emissions; however, $\mathrm{O}_{3}$ levels increase (by 0.003 $0.017 \mathrm{ppm}$ ) in most of the areas with the reduction of only $\mathrm{NO}_{\mathrm{x}}$ emissions. Such $\mathrm{O}_{3}$ changes suggest that $\mathrm{O}_{3}$ formation was under a VOC-limited regime and was depressed by high $\mathrm{NO}_{\mathrm{x}}$ levels in these urban areas and the immediate downwind areas during the campaign period, which is consistent with Zhang et al.'s (2008b) findings from an observationbased model at the GDEMC and Xinken sites. The $\mathrm{O}_{3}$ levels are more sensitive to the perturbation of $\mathrm{NO}_{\mathrm{x}}$ emissions but exhibit less changes with VOCs reductions in the rural southwestern PRD (i.e., the region marked by blue ellipse in Fig. 14), where less $\mathrm{NO}_{\mathrm{x}}$ and low-to-moderate VOC emissions are distributed (see Fig. 2). The $\mathrm{O}_{3}$ response supports the important role of $\mathrm{NO}_{\mathrm{x}}$ regional transport to $\mathrm{O}_{3}$ formation in the southwestern PRD, as obtained by the process analysis in Sect. 3.3.2. With reductions in both $\mathrm{NO}_{\mathrm{x}}$ and VOCs emissions, $\mathrm{O}_{3}$ levels decrease over most of the central and western PRD.

Next, we check the response of $\mathrm{O}_{3}$ photochemical production rates to the perturbations of precursor emissions because of the critical influence of gas-phase chemistry on $\mathrm{O}_{3}$ enhancement from low concentrations in morning to maximum levels in mid-afternoon over most parts of the central and western PRD. Figure 15a and b show that the responses of the net chemical production rates of $\mathrm{O}_{\mathrm{x}}\left[P\left(\mathrm{O}_{\mathrm{x}}\right)\right]$ are similar to the changes of $\mathrm{O}_{3}$ in the central and western PRD (see Fig. 14a and b), except for the obvious decrease in the eastern PRD with the reduction of $\mathrm{NO}_{\mathrm{x}}$ emissions (i.e., a clear 

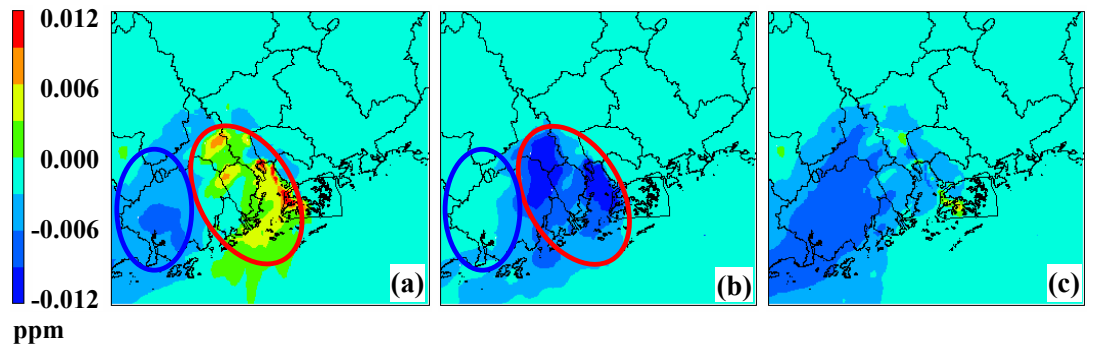

Fig. 14. Surface $\mathrm{O}_{3}$ change averaged over 12:00-17:00 LST on 16-22 October 2004 due to a $25 \%$ reduction in anthropogenic emissions of (a) $\mathrm{NO}_{\mathrm{x}}$ only, (b) VOCs only, and (c) both $\mathrm{NO}_{\mathrm{x}}$ and VOCs. The blue and red ellipses mark the regions with the $\mathrm{O}_{3}$ change characterized by $\mathrm{NO}_{\mathrm{x}}$-limited chemistry and by VOC-limited chemistry, respectively.

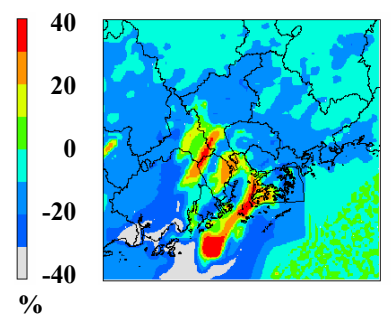

(a)

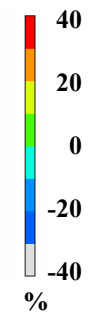

(b)
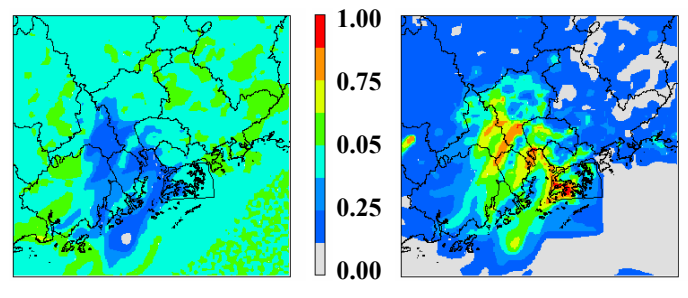

(c)

Fig. 15. Regional distribution of the percentage change in $P\left(\mathrm{O}_{\mathrm{x}}\right)$ due to a $25 \%$ reduction in anthropogenic emissions of $\mathrm{NO}_{\mathrm{x}}$ only $(\mathbf{a})$, VOCs only (b), and the $\mathrm{NO}_{\mathrm{x}} / \mathrm{NO}_{\mathrm{y}}$ ratio in the base case run (c) in the surface layer during 12:00-13:00 LST on 16 October 2004 .

$\mathrm{NO}_{\mathrm{x}}$-sensitive response). The distribution of the $\mathrm{NO}_{\mathrm{x}} / \mathrm{NO}_{\mathrm{y}}$ ratio is also presented for understanding the responses of $P\left(\mathrm{O}_{\mathrm{x}}\right)$ (Fig. 15c). The VOC-sensitive area over the PRD generally corresponds to the areas of higher $\mathrm{NO}_{\mathrm{x}} / \mathrm{NO}_{\mathrm{y}}$ ratios, whereas the decrease of $P\left(\mathrm{O}_{\mathrm{x}}\right)$ due to the reduction of $\mathrm{NO}_{\mathrm{x}}$ emissions usually occurs in the regions of lower $\mathrm{NO}_{\mathrm{x}} / \mathrm{NO}_{\mathrm{y}}$ ratios, similar to results from the Mexico City Metropolitan Area (Lei et al., 2007). Generally, in and near urban cores, air plumes are exposed to fresh pollutants (high $\mathrm{NO}_{\mathrm{x}} / \mathrm{NO}_{\mathrm{y}}$ ratios) and tend to fall into the VOC-limited regime and even the $\mathrm{NO}_{\mathrm{x}}$ disbenefit regime (i.e., an increase in $P\left(\mathrm{O}_{\mathrm{x}}\right)$ resulting from a decrease in $\mathrm{NO}_{\mathrm{x}}$ ). However, in suburban and rural regions, air plumes tend to maintain low $\mathrm{NO}_{\mathrm{x}} / \mathrm{NO}_{\mathrm{y}}$ due to the rapid removal of $\mathrm{NO}_{\mathrm{x}}$ by the chemical process in the course of transport to those regions, and $\mathrm{O}_{3}$ production also tends to shift from VOC-limited to $\mathrm{NO}_{\mathrm{x}}$-limited chemistry for the same reason (NARSTO, 2000).

We then further investigate the relationships between $P\left(\mathrm{O}_{\mathrm{x}}\right)$ changes and $\mathrm{NO}_{\mathrm{x}} / \mathrm{NO}_{\mathrm{y}}$ ratios at the GDEMC, Xinken, Donghu, Kaiping, and Duanfen sites (Fig. 16). Kaiping and Duanfen are located in the central and southern Jiangmen city, respectively (see Fig. 1), which are selected here to investigate $\mathrm{O}_{3}$ photochemical sensitivity in the southwestern inland and coastal areas of the PRD. Although the distribution of $\mathrm{NO}_{\mathrm{x}} / \mathrm{NO}_{\mathrm{y}}$ ratio shows significant difference (i.e., GDEMC is characterized by high ratios, but Kaiping and Duanfen are dominated by low values), the responses of $P\left(\mathrm{O}_{\mathrm{x}}\right)$

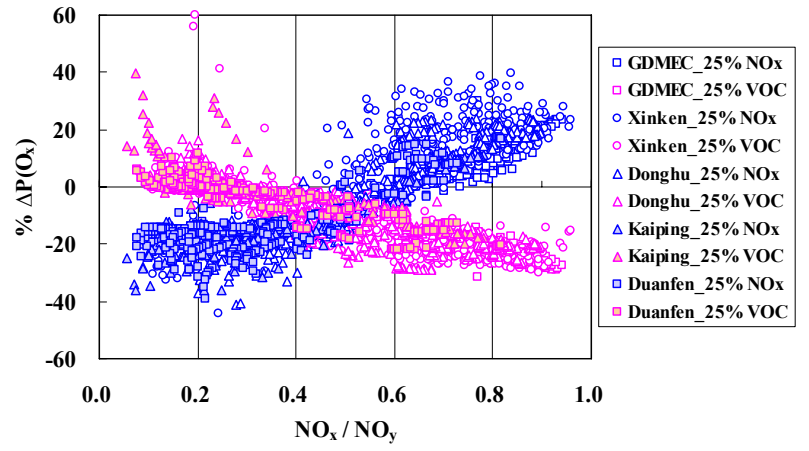

Fig. 16. The percentage change in $P\left(\mathrm{O}_{\mathrm{x}}\right)$ due to a $25 \%$ reduction in anthropogenic emissions of $\mathrm{NO}_{\mathrm{x}}\left(25 \% \mathrm{NO}_{\mathrm{x}}\right)$ and VOCs (25\%VOC) as a function of the $\mathrm{NO}_{\mathrm{x}} / \mathrm{NO}_{\mathrm{y}}$ ratio at the GDEMC, Xinken, Donghu, Kaiping, and Duanfen sites from layers 1 to 7 for the period of 09:00-17:00 LST during 16-22 October 2004.

share some common features at the five sites. In the case of $25 \%$ reduction of $\mathrm{NO}_{\mathrm{x}}$ emissions, the percentage change in $P\left(\mathrm{O}_{\mathrm{x}}\right)$ tends to increase from about $-30 \%$ to $30 \%$ with increasing $\mathrm{NO}_{\mathrm{x}} / \mathrm{NO}_{\mathrm{y}}$ ratio, whereas a decreasing tendency is obtained in the condition of VOCs emission reduction. The VOC benefit (i.e., a decrease in $P\left(\mathrm{O}_{\mathrm{x}}\right)$ resulting from a reduction in VOCs) and the $\mathrm{NO}_{\mathrm{x}}$ disbenefit suggest an obvious VOC-limited chemistry under higher $\mathrm{NO}_{\mathrm{x}} / \mathrm{NO}_{\mathrm{y}}$ conditions 
( $>0.6$, corresponding to fresh pollutants), whereas the opposite responses of $P\left(\mathrm{O}_{\mathrm{x}}\right)$ indicate the $\mathrm{NO}_{\mathrm{x}}$-limited regime occurring under lower $\mathrm{NO}_{\mathrm{x}} / \mathrm{NO}_{\mathrm{y}}$ conditions $(<0.3$, corresponding to chemically aged pollutants). The range of the $\mathrm{NO}_{\mathrm{x}} / \mathrm{NO}_{\mathrm{y}}$ ratio from about 0.4 to 0.6 seems to be a common transition between $\mathrm{NO}_{\mathrm{x}}$ - and VOC-limited chemistry at all five sites.

\section{Summary}

The MM5/SMOKE/CMAQ modeling system was applied to investigate $\mathrm{O}_{3}$ pollution over the PRD region during the PRIDE-PRD2004 campaign. Model performance was assessed by comparing simulated $\mathrm{O}_{3}, \mathrm{NO}_{\mathrm{x}}$, and $\mathrm{NMHC}$ concentrations with measurements from two super sites (GDEMC and Xinken) of the campaign and from PRD regional air quality monitoring networks. The model reasonably reproduced the ozone episodes observed during the 1month campaign.

Elevated $\mathrm{O}_{3}$ levels were usually observed in the southwestern inland PRD, PRE, and southern coastal areas, resulting from the intensive precursor emissions in the central PRD and the dominant northerly or easterly winds during October. Three evolution patterns of simulated surface $\mathrm{O}_{3}$ are categorized based on the different near-ground flow conditions, and more than $75 \%$ of the days occurred under the interaction between weak synoptic forcing and local sea-land circulation.

For daytime $\mathrm{O}_{3}$ evolution at the urban GDEMC site, gasphase chemistry serves as sink in lower layers $(0-80 \mathrm{~m}$ a.g.l.) but as a source in upper layers $(80-1000 \mathrm{~m}$ a.g.l.). The significant chemical removal of $\mathrm{O}_{3}$ near the surface is compensated by the contributions of vertical transport from upper layers and horizontal advection from upwind areas. The rural Xinken site is characterized by strong local circulations, resulting in significant vertical inflow and comparable horizontal outflow. In this area, photochemical production serves as a steady contributor during the daytime. The IPR results on overall $\mathrm{O}_{3}$ evolution in the ABL over the PRD suggest that photochemical production is the dominant contributor to $\mathrm{O}_{3}$ enhancement from 09:00 to 15:00 LST, and regions of high chemical production generally coincide with those of elevated $\mathrm{O}_{3}$ levels. The range of simulated OPE is $2-8 \mathrm{O}_{3}$ molecules per $\mathrm{NO}_{\mathrm{x}}$ molecule oxidized in most areas of high $\mathrm{O}_{3}$ chemical production.

Compared with previous studies, an in-depth understanding of the regional $\mathrm{O}_{3}$ formation over inland PRD area is obtained by process analysis. Through the transport process during nighttime and morning, $\mathrm{O}_{3}$ precursors originating from northern source areas (i.e. urban Guangzhou and Foshan) and from southern areas (i.e. Dongguan, Shenzhen and Hong Kong) are usually mixed and transported to western or southern rural areas, where they are then involved in the daytime $\mathrm{O}_{3}$ photochemical production. Such close interactions among precursor emissions, physical transport, and gas phase chemistry resulted in significant $\mathrm{O}_{3}$ chemical production on a large regional scale in the daytime. The sea-land circulations played an important role on the regional $\mathrm{O}_{3}$ formation and distribution over PRD during the campaign.

The $\mathrm{O}_{3}$ sensitivity to precursors was investigated by comparisons of simulated $\mathrm{O}_{3}$ levels between the base case and emission-control scenarios. Formation of $\mathrm{O}_{3}$ is VOC-limited and $\mathrm{NO}_{\mathrm{x}}$-depressed in the central inland PRD, PRE, and surrounding coastal areas, whereas $\mathrm{O}_{3}$ levels show more sensitivity to $\mathrm{NO}_{\mathrm{x}}$ in the rural southwestern PRD. The significant spatial variations of $\mathrm{O}_{3}$ production sensitivity show a close relationship to the chemical aging of air plumes. VOClimited chemistry usually dominates in less chemically aged air $\left(\mathrm{NO}_{\mathrm{x}} / \mathrm{NO}_{\mathrm{y}}>0.6\right)$, whereas $\mathrm{NO}_{\mathrm{x}}$-limited chemistry generally occurs within chemically aged plumes $\left(\mathrm{NO}_{\mathrm{x}} / \mathrm{NO}_{\mathrm{y}}<0.3\right)$.

The spatial variation of $\mathrm{O}_{3}$ formation sensitivity suggests a non-uniform precursor emission-reduction strategy for $\mathrm{O}_{3}$ pollution control in sub-regions of the PRD. Considering the source emissions concentrated in urban areas and the significant precursor transport to downwind rural areas, reductions in both VOC and $\mathrm{NO}_{\mathrm{x}}$ emissions, combined with more emphasis on VOC controls, appear to be practical for lowering the $\mathrm{O}_{3}$ levels over the PRD region.

Acknowledgements. This work was supported by the National High Technology Research and Development Program of China (Grant No. 2006AA06A306), the European Union's Seventh Framework Programme (FP7/2007-2013, Grant No. 212095), the Public Welfare Projects for Environmental Protection (Grant No. 200809018) and the National Basic Research Program of China (Grant No. 2002CB410801). The authors are grateful to Peter Louie (Hong Kong Environmental Protection Department) for supplying the emission data, to Shaojia Fan (Sun Yat-sen University) for supporting meteorological observation data, to Jia-Lin Wang (National Central University, Taiwan), Shaw Liu and Chih-Chung Chang (Academia Sinica, Taiwan) for providing NMHC online measurement data, and to Yang Zhang (North Carolina State University, Raleigh, USA) for her valuable suggestions. The authors also acknowledge the constructive comments from the anonymous reviewers.

Edited by: I. Trebs

\section{References}

Byun, D. and Schere, K. L.: Review of the governing equations, computational algorithms, and other components of the Models3 Community Multiscale Air Quality (CMAQ) modeling system, Appl. Mech. Rev., 59, 51-77, 2006.

Cao, G., Zhang X., Wang D., and Zheng, F.: Inventory of atmospheric pollutants discharged from biomass burning in China continent, China Environmental Science, 25(4), 389-393, 2005 (in Chinese).

Carter, W. P. L.: Documentation of the SAPRC-99 chemical mechanism for VOC reactivity assessment, Final Report to California Air Resources Board, Contract No. 92-329 and 95-308, 2000. 
Chan, C. Y. and Chan., L. Y.: Effect of meteorology and air pollutant transport on ozone episodes at a subtropical coastal Asian city, Hong Kong, J. Geophys. Res., 105(D16), 20707-20724, 2000.

Chan, C. K. and Yao, X.: Air pollution in mega cities in China, Atmos. Environ., 42, 1-42, 2008.

Chang, K. H.: Modeling approach for emission reduction of $\mathrm{O}_{3}$ precursors in Southern Taiwan, Atmos. Environ., 42(28), 67336742, 2008.

Chou, C. C. K., Liu, S. C., Lin, C. Y., Shiu, C. J., and Chang, K. H.: The trend of surface ozone in Taipei, Taiwan, and its causes: Implications for ozone control strategies, Atmos. Environ., 40, 3898-3908, 2006.

Chou, C. C. K., Tsai, C. Y., Shiu, C. J., Liu, S. C., and Zhu, T.: Measurement of $\mathrm{NO}_{\mathrm{y}}$ during Campaign of Air Quality Research in Beijing 2006 (CAREBeijing-2006): Implications for the ozone production efficiency of $\mathrm{NO}_{\mathrm{x}}$, J. Geophys. Res., 114, D00G01, doi:10.1029/2008JD010446, 2009.

Ding, A., Wang, T., Zhao, M., Wang, T., and Li, Z. K.: Simulation of sea-breezes and a discussion of their implications on the transport air pollution during a multi-day ozone episode in the Pearl River Delta of China, Atmos. Environ., 12(29), 6737-6750, 2004.

Emery, C. A., Tai, E., and Yarwood, G.: Enhanced meteorological modeling and performance evaluation for two Texas ozone episodes, Project Report prepared for the Texas Natural Resource Conservation Commissions, ENVIRON International Corporation, Novato, CA, 2001.

Evtyugina, M. G., Nunes, T., Pio, C., and Costa, C. S.: Photochemical pollution under sea breeze conditions, during summer, at the Portuguese West Coast, Atmos. Environ., 40(33), 6277-6293, 2006.

Fan, S. J., Wang, B. M., Tesche, M., Engelmann, R., Althausen, A., Liu, J., Zhu, W., Fan, Q., Li, M. H., Ta, N., Song, L. L., and Leong, K. C.: Meteorological conditions and structures of atmospheric boundary layer in October 2004 over Pearl River Delta area, Atmos. Environ., 42, 6174-6186, 2008.

Gipson, L. G.: Science Algorithms of the EPA Models-3 Community Multiscale Air Quality (CMAQ) Modeling System: process analysis, EPA/600/R-99/030, US EPA, online available at: http://www.epa.gov/asmdnerl/CMAQ/ch16.pdf, 37 pp., 1999.

Gonçalves, M., Jiménez-Guerrero, P., and Baldasano, J. M.: Contribution of atmospheric processes affecting the dynamics of air pollution in South-Western Europe during a typical summertime photochemical episode, Atmos. Chem. Phys., 9, 849-864, 2009, http://www.atmos-chem-phys.net/9/849/2009/.

Grell, G. A., Dudhia, J., and Stanffer, D. R.: A description of the Fifth-generation Penn State/NCAR Mesoscale Model (MM5), NCAR Technical Note: NCAR/TN-398+STR, 1994.

Hanna, S. R. and Yang, R. X.: Evaluations of mesoscale models' simulations of near-surface winds, temperature gradients, and mixing depths, J. Appl. Meteorol., 40(6), 1095-1104, 2001.

Houyoux, M. R., Vukovich, J. M., Coats Jr., C. J., Wheeler, N. J. M., and Kasibhatla, P.: Emission inventory development and processing for the seasonal model for regional air quality, J. Geophys. Res., 105(D7), 9079-9090, 2000.
Huang, J. P., Fung, J. C. H., Lau, A. K. H., and Qin, Y.: Numerical simulation and process analysis of typhoon-related episodes in Hong Kong, J. Geophys. Res., 110, D05301, doi:10.1029/2004JD004914, 2005.

Huang, J. P., Fung, J. C. H., and Lau, A. K. H.: Integrated processes analysis and systematic meteorological classification of ozone episodes in Hong Kong, J. Geophys. Res., 111, D20309, doi:10.1029/2005JD007012, 2006.

Jang, J. C., Jeffries, H. E., Byun, D., and Pleim, J. E.: Sensitivity of ozone to model grid resolution - I. Application of highresolution regional acid deposition model, Atmos. Environ., 21, 3085-3100, 1995.

Jeffries, H. E. and Tonnesen, S.: A comparison of two photochemical reaction mechanisms using mass balance and process analysis, Atmos. Environ., 28, 2991-3003, 1994.

Kimura, Y., McDonald-Buller, E., Vizuete, W., and Allen, D. T.: Application of a Lagrangian Process Analysis tool to characterize ozone formation in Southeast Texas, Atmos. Environ., 42(23), 5743-5759, 2008.

Kleinman, L. I., Daum, P. H., Imre, D. G., Lee, J. H., Lee, Y. N., Nunnermacker, L. J., Springston, S. R., Weinstein-Lloyd, J., and Newman, L.: Ozone production in the New York City urban plume, J. Geophys. Res., 105(D11), 14495-14511, 2000.

Lam, K. S., Wang, T. J., Wu, C. L., and Li, Y. S.: Study on an ozone episode in hot season in Hong Kong and transboundary air pollution over Pearl River Delta region of China, Atmos. Environ., 39, 1967-1977, 2005.

Lei, W., de Foy, B., Zavala, M., Volkamer, R., and Molina, L. T.: Characterizing ozone production in the Mexico City Metropolitan Area: a case study using a chemical transport model, Atmos. Chem. Phys., 7, 1347-1366, 2007, http://www.atmos-chem-phys.net/7/1347/2007/.

Liu, H. and Chan, J. C. L.: An investigation of air-pollutant patterns under sea-land breezes during a severe air-pollution episode in Hong Kong, Atmos. Environ., 36, 591-601, 2002.

Liu, J. F., Zhao, J., Li, T. T., Bai, Y. H., and Liu, Z. R.: Establishment of Chinese anthropogenic source volatile organic compounds emission inventory, China Environmental Science, 28(6), 496-500, 2008a (in Chinese).

Liu, Y., Shao, M., Lu, S. H., Liao, C. C., Wang, J. L., and Chen, G.: Volatile Organic Compound (VOC) measurements in the Pearl River Delta (PRD) region, China, Atmos. Chem. Phys., 8, 15311545, 2008b, http://www.atmos-chem-phys.net/8/1531/2008/.

Lo, J. C. F., Lau, A. K. H., Fung, J. C. H., and Chen, F.: Investigation of enhanced cross-city transport and trapping of air pollutants by coastal and urban land-sea breeze circulations, J. Geophys. Res., 111, D14104, doi:10.1029/2005JD006837, 2006.

NARSTO: An Assessment of Tropospheric Ozone Pollution: A North American Perspective, The NARSTO Synthesis Team, Palo Alto, CA, 2000.

Nunnermacker, L. J., Imre, D., Daum, P. H., Kleinman, L., Lee, Y. N., Lee, J. H., Springston, S. R., Newman, L., Weinstein-Lloyd, J., Luke, W. T., Banta, R., Alvarez, R., Senff, C., Sillman, S., Holdren, M., Keigley, G. W., and Zhou, X.: Characterization of the Nashville urban plume on July 3 and July 18, 1995, J. Geophys. Res., 103(D21), 28129-28148, 1998. 
Pearl River Delta environmental protection planning committee: Pearl River Delta environmental protection planning, China environmental science press, Beijing, 2006.

Ran, L., Zhao, C., Geng, F., Tie, X., Tang, X., Peng, L., Zhou, G., Yu, Q., Xu, J., and Guenther, A.: Ozone photochemical production in urban Shanghai, China: analysis based on ground level observations, J. Geophys. Res., 114, D15301, doi:10.1029/2008JD010752, 2009.

Seinfeld, J. H. and Pandis, S. N.: Atmospheric chemistry and physics: From air pollution to climate change (Second edition), John Wiley \& Sons, Inc., Hoboken, New Jersey, 2006.

Shao, M., Zhang, Y. H., Zeng, L. M., Tang, X. Y., Zhang, J., Zhong, L. J., and Wang, B. G.: Ground-level ozone in the Pearl River Delta and the roles of VOC and $\mathrm{NO}_{\mathrm{x}}$ in its production, J. Environ. Manage., 90, 512-518, 2009.

Sillman, S.: The use of $\mathrm{NO}_{y}, \mathrm{H}_{2} \mathrm{O}_{2}$, and $\mathrm{HNO}_{3}$ as indicators for ozone- $\mathrm{NO}_{\mathrm{x}}$-hydrocarbon sensitivity in urban locations, J. Geophys. Res., 100(D7), 14175-14188, 1995.

Sillman, S. and He, D. Y.: Some theoretical results concerning O3- $\mathrm{NO}_{\mathrm{x}}$-VOC chemistry and $\mathrm{NO}_{\mathrm{x}}$-VOC indicators, J. Geophys. Res., 107(D22), 4659, doi:10.1029/2001JD001123, 2002.

Steinbacher, M., Zellweger, C., Schwarzenbach, B., Bugmann, S., Buchmann, B., Ordóñez, C., Prevot, A. S. H., and Hueglin, C.: Nitrogen oxide measurements at rural sites in Switzerland: bias of conventional measurement techniques, J. Geophys. Res., 112, D11307, doi:10.1029/2006JD007971, 2007.

Streets, D. G., Bond, T. C., Carmichael, G. R., Fernandes, S. D., Fu, Q., He, D., Klimont, Z., Nelson, S. M., Tsai, N. Y., Wang, M. Q., Woo, J. H., and Yarber, K. F.: An inventory of gaseous and primary aerosol emissions in Asia in the year 2000, J. Geophys. Res., 108(D21), 8809, doi:10.1029/2002JD003093, 2003.

Song, X. Y. and Xie, S. D.: Development of vehicular emission inventory in China, Environmental Science, 27(6), 1041-1045, 2006 (in Chinese).

Vukovich, J. M. and Pierce, T.: The implementation of BEIS3 within the SMOKE modeling framework, online available at: http://www.epa.gov/ttn/chief/conference/ei11/modeling/ vukovich.pdf, 2002.

Wang, J. L., Wang, C. H., Lai, C. H., Chang, C. C., Liu, Y., Zhang, Y. H., Liu, S., and Shao, M.: Characterization of ozone precursors in the Pearl River Delta by time series observation of nonmethane hydrocarbons, Atmos. Environ., 42, 6233-6246, 2008a.

Wang, K., Zhang, Y., Jang, C., Phillips, S., and Wang, B. Y.: Modeling intercontinental air pollution transport over the trans-Pacific region in 2001 using the Community Multiscale Air Quality modeling system, J. Geophys. Res., 114, D04307, doi:10.1029/2008JD010807, 2009.

Wang, T., Poon, C. N., Kwok, Y. H., and Li, Y. S.: Characterizing the temporal variability and emission patterns of pollution plumes in the Pearl River Delta of China, Atmos. Environ., 37, 3539-3550, 2003.

Wang, T., Wu, Y. Y., Cheung, T. F., and Lam. K. S.: A study of surface ozone and the relation to complex wind flow in Hong Kong, Atmos. Environ., 35, 3203-3215, 2001.

Wang, T. J., Lam, K. S., Xie, M., Wang, X. M., Carmichael, G., and Li, Y. S.: Integrated studies of a photochemical smog episode in Hong Kong and regional transport in the Pearl River Delta of China, Tellus, 58B, 31-40, 2006.
Wang, W., Ren, L. H., Zhang, Y. H., Chen, J. H., Liu, H. J., Bao, L. F., Fan, S. J., and Tang, D. G.: Aircraft measurements of gaseous pollutants and particulate matter over Pearl River Delta in China, Atmos. Environ., 42, 6187-6202, 2008b.

Wang, X., Carmichael, G., Chen, D., Tang, Y., and Wang, T.: Impacts of different emission sources on air quality during March 2001 in the Pearl River Delta (PRD) region, Atmos. Environ., 39, 5227-5241, 2005.

Wang X. S., Li, J. L., Zhang, Y. H., Xie, S. D., and Tang, X. Y.: Ozone source attribution during a severe photochemical smog episode in Beijing, China, Sci. China Ser. B-Chem., 52(8), 12701280, 2009.

Wei, X. L., Li, Y. S., Lam, K. S., Wang, A. Y., and Wang, T. J.: Impact of biogenic VOC emissions on a tropical cyclone-related ozone episode in the Pearl River Delta region, China, Atmos. Environ., 41, 7851-7864, 2007.

Xu, J., Zhang, Y. H., Fu, J. S., Zheng, S. Q., and Wang, W.: Process analysis of typical summertime ozone episodes over the Beijing area, Sci. Total Environ., 399, 147-157, 2008.

Yu, S., Mathur, R., Kang, D., Schere, K., and Tong, D.: A study of the ozone formation by ensemble back trajectory-process analysis using the Eta-CMAQ forecast model over the northeastern U.S. during the 2004 ICARTT period, Atmos. Environ., 43, 355 363, 2009.

Zhang, J., Wang, T., Chameides, W. L., Cardelino, C., Kwok, J., Blake, D. R., Ding, A., and So, K. L.: Ozone production and hydrocarbon reactivity in Hong Kong, Southern China, Atmos. Chem. Phys., 7, 557-573, 2007, http://www.atmos-chem-phys.net/7/557/2007/.

Zhang, Y., Liu, P., Queen, A., Misenis, C., Pun, B., Seigneur, C., and Wu, S.-Y.: A comprehensive performance evaluation of MM5-CMAQ for the Summer 1999 Southern Oxidants Study episode - Part II: Gas and aerosol predictions, Atmos. Environ., 40, 4839-4855, 2006.

Zhang, Y., Vijayaraghavan, K., Wen, X.-Y., Snell, H. E., and Jacobson, M. Z.: Probing into regional $\mathrm{O}_{3}$ and $\mathrm{PM}$ pollution in the U.S., Part I. A 1-year CMAQ simulation and evaluation using surface and satellite data, J. Geophys. Res., 114, D22304, doi:10.1029/2009JD011898, 2009a.

Zhang, Y., Wen, X.-Y., Wang, K., Vijayaraghavan, K., and Jacobson, M. Z.: Probing into regional $\mathrm{O}_{3}$ and $\mathrm{PM}$ pollution in the U.S., Part II. An examination of formation mechanisms through a process analysis technique and sensitivity study, J. Geophys. Res., 114, D22305, doi:10.1029/2009JD011900, 2009b.

Zhang, Y. H., Hu, M., Zhong, L. J., Wiedensohler, A., Liu, S. C., Andreae, M. O., Wang, W., and Fan, S. J.: Regional integrated experiments on air quality over Pearl River Delta 2004 (PRDIEPRD2004): Overview, Atmos. Environ., 42, 6157-6173, $2008 \mathrm{a}$.

Zhang, Y. H., Su, H., Zhong, L. J., Cheng, Y. F., Zeng, L. M., Wang, X. S., Xiang, Y. R., Wang, J. L., Gao, D. F., Shao, M., Fan, S. J., and Liu, S. C.: Regional ozone pollution and observation-based approach for analyzing ozone-precursor relationship during the PRIDE-PRD2004 campaign, Atmos. Environ., 42, 6203-6218, 2008b. 